INTER NATIONAL MONETARY FUND
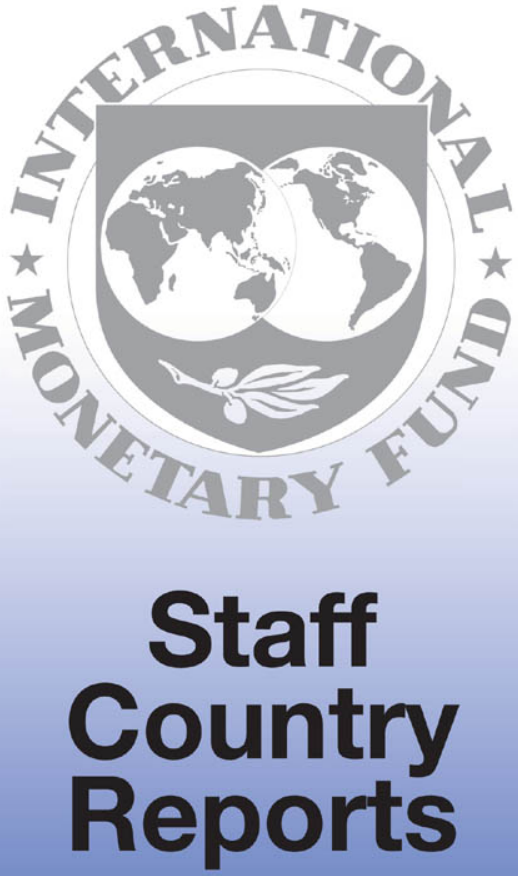
O1999 International Monetary Fund

September 1999

IMF Staff Country Report No. 99/103

\section{New Zealand: Staff Report for the 1999 Article IV Consultation}

This report was prepared by a staff team of the International Monetary Fund following discussions with the officials of New Zealand on economic developments and policies. The report was then considered by the IMF's Executive Board in the context of the IMF's periodic consultation with New Zealand, as required under Article IV of the IMF Articles of Agreement. The views expressed in the staff report itself are those of the staff team and do not necessarily reflect the views of the Executive Board of the IMF or of the authorities of New Zealand; a supplementary statement by IMF staff may also be included. The views of the Executive Board as expressed in the discussion of the Article IV consultation report and as summarized in a Public Information Notice (PIN) are also included. In addition, a statement by the member country authorities may be appended. Further background documentation prepared by IMF staff for the consultation may be published separately at a later date. The policy of publication of Article IV staff reports allows for the deletion of market sensitive information.

This Article IV staff report is published-both in hard copy and on the IMF's website (http://www.imf.org) - as part of a pilot project. To assist the IMF in evaluating the pilot project for release of Article IV staff reports, reader comments on the staff report are invited prior to October 5, 2000, and may be sent by e-mail to Pilotproject@imf.org.

Copies of this report are available to the public from

International Monetary Fund • Publication Services 700 19th Street, N.W. • Washington, D.C. 20431

Telephone: (202) 623-7430 • Telefax: (202) 623-7201

Telex (RCA): 248331 IMF UR

E-mail: publications@imf.org

Internet: http://www.imf.org

Price: $\$ 15.00$ a copy

\section{International Monetary Fund \\ Washington, D.C.}




\section{INTERNATIONAL MONETARY FUND}

\section{NEW ZEALAND \\ Staff Report for the 1999 Article IV Consultation}

Prepared by the Staff Representatives for

the 1999 Consultation with New Zealand

Approved by Wanda Tseng and Thomas Leddy

August 2, 1999

- The 1999 Article IV consultation discussions were held in Wellington during May 31-June 8, 1999.

The mission team consisted of Messrs. Ostry (Head), Aziz, Lee, and Sarel (all APD). Mr. Woolford (Advisor to the Executive Director for New Zealand) attended some of the meetings.

- The mission met with Treasurer Birch, Reserve Bank Governor Brash, Treasury Secretary Bollard, senior government officials, and private and financial sector representatives.

- New Zealand has accepted the obligations of Article VIII, Sections 2, 3, and 4, and maintains an exchange system that is free of restrictions on the making of payments and transfers for current international transactions.

New Zealand publishes an array of high-quality statistics. Balance of payments financial account data, however, are published only after a lag of more than one year, although the timeliness and frequency of such data are being upgraded.

The principal author of this staff report is Mr. Ostry. 


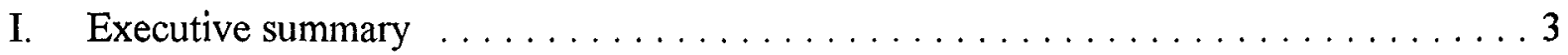

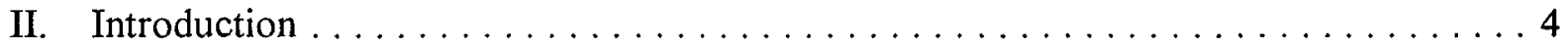

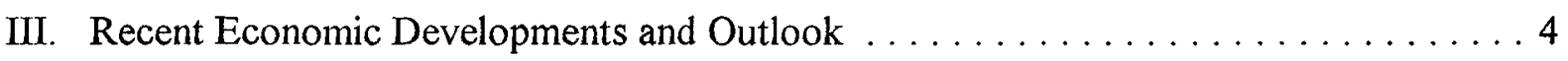

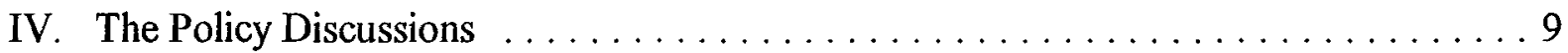

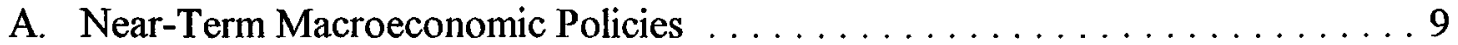

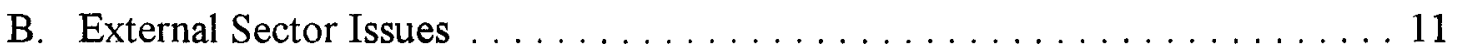

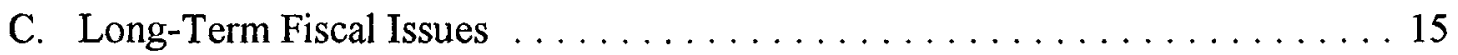

D. Structural Reform and Productivity Growth $\ldots \ldots \ldots \ldots \ldots$

V. Staff Appraisal

Text Boxes

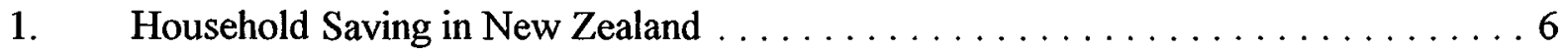

2. Modifications to the Reserve Bank's Operating Framework . . . . . . . . . 8

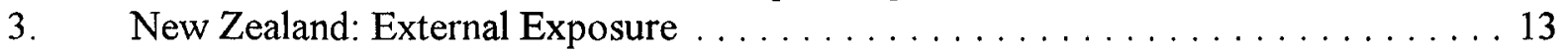

4. Productivity and Potential Growth $\ldots \ldots \ldots \ldots \ldots \ldots \ldots$

\section{Figures}

1. Selected Real Economic Indicators, 1994-1999 . . . . . . . . . . . . . . . 23

2. Monetary and Financial Indicators, $1994-1999 \ldots \ldots \ldots \ldots$. . . . . . . . 24

3. Balance of Payments and External Indicators, $1994-1999 \ldots \ldots \ldots \ldots 25$

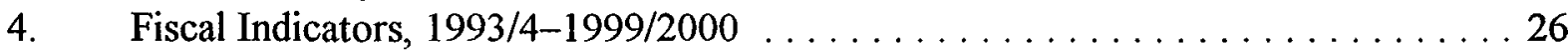

5. Labor Market and Inflation Indicators, $1994-1999 \ldots \ldots \ldots \ldots \ldots$. . . . . . . . . 27

Tables

1. Selected Economic and Financial Indicators, $1995-2000$. . . . . . . . . . . 28

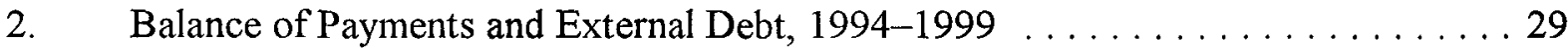

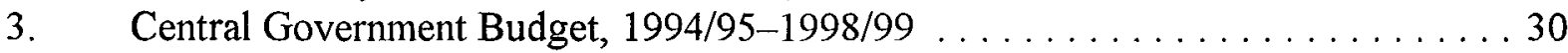

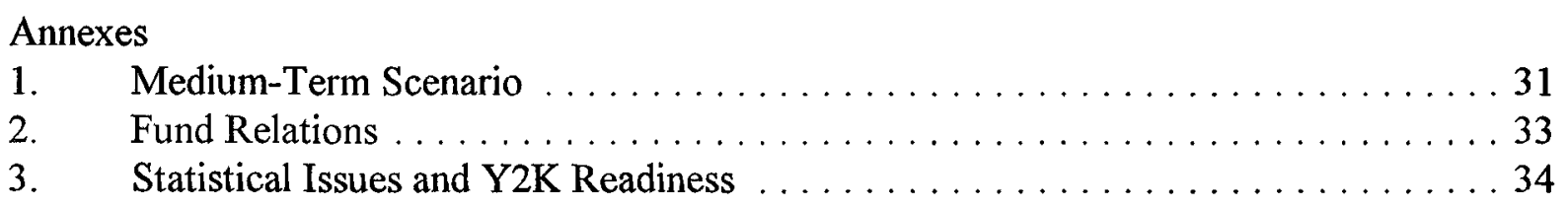




\section{EXECUTIVE SUMMARY}

- Following the recession in the first half of 1998, the New Zealand economy began a modestly-paced recovery, with growth of about $2 \frac{1}{2}$ percent projected for 1999 and a modest further pickup in 2000-01. Inflation remains subdued, but the sizable current account deficit - at $6 \frac{1}{2}$ percent in 1997-98-is expected to widen slightly in 1999, before narrowing over the medium term. As a result, New Zealand's already high level of net external liabilities will rise further, peaking above 100 percent of GDP in 2003.

- The magnitude of the external imbalance increases the possibility of a shift in market sentiment that could raise the risk premium and put pressure on the exchange rate, but a number of factors-including widespread hedging of exchange rate changes and the pure floating exchange rate regime-should mitigate the potential cost of such shocks.

- Near-term policies are appropriate, given the risks to the economy. Inflation is expected to remain near $1 \frac{1}{2}$ percent, the midpoint of the target band, over the 1-2 year policy horizon. Despite a cyclical deterioration in the fiscal balance, a deficit is being avoided this year owing to earlier measures to curb expenditure.

- The authorities are projecting rising budget surpluses through 2001/02 owing to continued expenditure restraint. The mission emphasized the benefits of overachieving somewhat on the envisaged pace of fiscal consolidation during this period in order to bolster confidence while the current account deficit remains at high levels.

- The authorities have taken some steps to reform the state pension system and are considering other options to address long-term demographic pressures on the budget. The mission emphasized the benefits of continued expenditure control and the buildup of somewhat larger fiscal surpluses over the medium term than are foreseen for the next two years, given longer-term fiscal pressures.

- Apart from fiscal consolidation, the mission emphasized the importance of removing potential disincentives to private saving resulting from the tax, pension, and welfare systems, in order to underpin market confidence and external adjustment. Pension reforms were expected to have a positive impact on private saving, as were ongoing measures to reduce welfare dependency. The mission noted that the relatively high share of revenue collected through direct taxation could also act as a disincentive to private saving, and recommended consideration of tax reform as a possible remedy.

- Productivity growth has increased during the 1990 s-relative to the pre-reform period of the 1970 s and early 1980 s-although this may partly reflect cyclical factors. The authorities and mission agreed that the structural reform agenda was well-focused at present, and was likely to yield further benefits over time. 


\section{INTRODUCTION}

1. Since the mid-1980s, New Zealand has been engaged in a comprehensive reform effort designed to improve its economic performance. On the structural side, reforms have included the adoption of a freely floating exchange rate regime; financial and trade liberalization; product and labor market deregulation; and public enterprise reform and privatization. On the macroeconomic side, New Zealand has been at the forefront internationally of efforts to improve policy transparency, including through passage in the late 1980s of the Reserve Bank Act - which established the central bank's independence and the single objective of price stability for monetary policy-and the introduction of the Fiscal Responsibility Act (FRA) in the mid-1990s - which lays out principles of responsible fiscal management and improves accountability in relation to those principles.

2. Economic performance has improved during the 1990s relative to the previous decade. Inflation has averaged about 2 percent, compared to nearly 10 percent in the 1980 s. Economic growth has picked up to $2 \frac{1 / 4}{4}$ percent this decade, significantly faster than in the 1980s. And, thanks to strong budget surpluses, net public debt has been reduced by half over the past decade, and has now reached relatively low levels by international standards.

3. Two significant economic challenges remain at center-stage, however: the vulnerabilities associated with New Zealand's external imbalance; and the still unsatisfactory rate of potential growth. Policies to address these challenges were the focus of the discussions. New Zealand's current account deficit averaged $61 / 2$ percent of GDP in $1997-98$, contributing to a further rise in the country's already very high net external liabilities ratio. While New Zealand's growth performance is likely to have been positively affected by microeconomic reforms instituted since the mid-1980s, most estimates of potential growth suggest that the rate remains too low to close the per capita income gap-about 20 percent at present-between New Zealand and the advanced-economy average.

4. An election is due to be held by year-end. Economic issues_-including tax and expenditure policy - are likely to feature prominently in the campaign.

\section{RECENT ECONOMIC DEVELOPMENTS AND OUTLOOK}

5. Since the last Article IV consultation (SM/97/257, 10/17/97), New Zealand was hit by a string of unfavorable shocks which, combined with high real interest rates and a strong New Zealand dollar in 1996-97, served to push the economy into recession at the beginning of 1998 (Figure 1). In addition to the collapse in demand from crisis-hit Asia (which, including Japan, accounts for nearly two-fifths of New Zealand's export markets), the economy was affected by severe drought which depressed agricultural output and exports, and by continued weakness in the terms of trade. Overlaid on these shocks was the impact of very firm monetary conditions that had been established in a period when forecasts portended continued strong demand growth. Given the lags between monetary conditions and demand, 
the firmness of conditions in 1996-97 is likely to have exacerbated the economic impact of external and domestic supply shocks.

6. Recession proved short-lived, however, and a recovery was underway by the second half of 1998, aided by an easing in both monetary and fiscal policies. Indeed, monetary conditions were eased significantly through 1997-98-with interest rates declining by half and the trade-weighted exchange rate falling by nearly 20 percent (Figure 2)-which bolstered both net exports and domestic demand. The latter was also underpinned by income tax cuts that were implemented in mid-1998, and by the elimination of tariffs on automobiles at about the same time, which boosted car sales strongly.

7. The current account deficit narrowed in 1998, reflecting the weakness of the domestic economy and competitiveness gains, but remained well above the level that would stabilize the net external liabilities ratio (Tables 1,2 ; Figure 3 ). While the recession dampened imports and corporate dividend payments to nonresidents, other factors-including weak cyclical conditions abroad; adverse terms of trade; agricultural supply constraints; and poor returns on foreign investments - prevented a stronger improvement. As a result, the net external liabilities ratio-already the highest among industrial countries—rose further in 1998.

8. Despite the narrowing in 1998 , the current account deficit widened sharply during the 1990s as a whole, reflecting mainly a decline in national saving (Table below).

New Zealand: Saving, Investment, and the Current Account, 1992-99 (In percent of GDP)

\begin{tabular}{lcc}
\hline & $1992-93$ & $\begin{array}{c}1998-99 \\
\text { (Staff Proj.) }\end{array}$ \\
\hline National saving 1/ & 15.2 & 12.6 \\
Private saving & 14.5 & 8.6 \\
Public saving & 0.8 & 3.8 \\
Gross capital formation & 18.6 & 19.2 \\
Current account balance & -2.0 & -6.4 \\
Memorandum items (in percent): & & \\
$\quad$ Household debt/disposable income & 66.7 & 96.0 \\
Output gap 1/ & -2.0 & -1.7 \\
\hline
\end{tabular}

1/ Staff estimates; based on national accounts data.

The main factor accounting for this fall is lower private saving, as financial deregulation and a pickup in household income growth led to an acceleration in consumer borrowing (Box 1). As a result, household debt in New Zealand has followed a similar path to that observed in a number of countries following deregulation of consumer credit markets and-at 95 percent of disposable income in 1998-is slightly below levels reached in Canada and the United States. 
Box 1. Household Saving in New Zealand

- New Zealand's household saving rate declined from 5 percent of disposable income in 1990 to minus $1 / 4$ percent in 1998 . While household saving has been declining since the mid-1980s, the decline accelerated over the past five years, widening the gap between New Zealand's household saving rate and the median rate among industrialized countries (which has averaged more than 3 percentage points since the mid-1970s).

- A recent study by the staff (SM/97/262 and WP/97/181) found that New Zealand's low household saving rate (in comparison to other industrial countries) reflected the following principal factors: a relatively high reliance on direct taxes as a source of government revenue; higher net government transfers to households (including social welfare benefits); and New Zealand's relatively low economic growth rate in the period prior to reform. In addition, in terms of the time series behavior, the staff study found that fiscal consolidation had contributed to a reduction in household saving during the $1990 \mathrm{~s}$, with an estimated offset coefficient of about 40 percent. Other key factors lowering household saving over the past decade included lower inflation and higher household net worth, as house prices rose significantly between 1990 and 1996 (house prices have leveled off since then, and household net worth declined in 1998).

- The mission team undertook a further analysis of the behavior of New Zealand's household saving rate during the $1990 \mathrm{~s}$, especially in order to ascertain the possible role of financial deregulation, which in a number of industrial countries-e.g., the United Kingdom, the United States, France-was found to be a significant driving force behind declining household saving rates. Proxying financial deregulation by the outstanding stock of consumer credit (relative to GDP)-similar to the proxy used in a number of other studies ${ }^{1}$ - the financial deregulation variable was able to account for about half the decline in New Zealand's household saving rate during the 1990s, although the small size of the sample suggests that a cautious interpretation of the results may be warranted. The regression also confirmed the role of fiscal policy obtained in the earlier panel study. The combined effects of higher budget surpluses, stronger growth (which raises household saving), and the lagged impact of financial deregulation, were able to account for most of the decline in New Zealand's household saving during the 1990s.

' See T. Bayoumi, "Financial Deregulation and Household Saving," Economic Journal (1993) for the evidence on the United Kingdom; J. Ostry and J. Levy, "Household Saving in France," IMF Staff Papers (1995) for the evidence on France; and SM/99/164 for the evidence on the United States. 
9. Importantly, current account deficits since the mid-1990s have coexisted with fiscal surpluses, consistent with a key tenet of the FRA, which requires that public debt be reduced to "prudent" levels. In this vein, significant operating surpluses over the past five years have been used to pay down public debt which-at about 22 percent of GDP in net terms-stands 7 percent above the authorities' stated long-term target (Table 3; Figure 4). Less progress has been made in respect of another long-term objective-to reduce government spending below 30 percent of GDP-mainly because of pressures to increase social expenditure. As a result, the spending ratio stood at 35 percent in 1998/99, about its average rate since mid-decade, although well below rates posted in the late $1980 \mathrm{~s}$.

10. The budgetary outturn for $\mathbf{1 9 9 8 / 9 9}$ includes several one-off factors that boosted the operating surplus in that year, but that have no impact on the structural fiscal position. ${ }^{1}$ Adjusting for these, and for cyclical factors, the structural balance-while still in surplus - is significantly lower than its average level since the mid-1990s. The main factor explaining the fall in the structural surplus in 1998/99 is personal income tax cuts introduced in mid-1998 worth about 1 percent of GDP, the second such tax cut since mid-1996.

\section{Monetary policy has continued to be directed at achieving annual inflation} (excluding credit services, CPIX) of between 0 and 3 percent, consistent with the December 1997 Policy Targets Agreement (Figure 5). Monetary conditions began to ease in early 1997, and the easing gathered momentum in 1998 as the severity of the adverse shocks to which the New Zealand economy had been exposed - and their implications for future inflationary pressure-became fully appreciated. With recovery underway by the second half of 1998 and inflation projections having troughed, a modest firming took place during the course of 1999, although the Monetary Conditions Index (MCI) remains significantly easier than in early 1998.

\section{From March 1999, the Reserve Bank began to use the Official Cash Rate (OCR)} as its primary policy instrument (Box 2). The previous regime, under which policy was conducted through periodic announcements about the desired level of the $\mathrm{MCI}$, was replaced, in part reflecting the view that changes in the OCR constitute a more effective means of signaling policy intentions than public comments about prevailing monetary conditions. In setting the OCR, the Bank will review the impact of shocks - including to the exchange rate-on the inflationary outlook. When new information leaves the outlook 6-8 quarters ahead unaffected - as, e.g., could be the case when the exchange rate moves as a result of some real shock, say to the terms of trade-the OCR will remain unchanged. The MCI remains an important indicator of monetary conditions, although it will no longer be used to signal the Bank's short-term policy intentions.

\footnotetext{
${ }^{1}$ The most important such factor relates to privatization receipts, where the excess of proceeds over the book value of the asset is a revenue item in the budget. Privatization of Contact Energy in May 1999 added about 11/2 percent of GDP to the 1998/99 operating balance.
} 


\section{Box 2. Modifications to the Reserve Bank's Operating Framework}

Earlier this year, the Reserve Bank announced its intention to adopt, with effect from March 17, an Official Cash Rate (OCR) target as the primary instrument for conducting monetary policy. The previous operating regime, under which monetary policy was conducted through periodic announcements about the desired level of the Monetary Conditions Index (MCI) - a weighted average of short-term interest rates and the tradeweighted index of the New Zealand dollar-and official comments about the actual level of the MCI, was replaced, and the previous formal instrument - the daily settlement cash target - which was rarely used, was also abandoned. However, neither the inflation target itself, nor the weights placed on various indicators - including the $\mathrm{MCI}$ - used in deciding the appropriate policy stance, are affected by the change in the operating framework.

The adoption of the new framework was motivated by several factors. In particular, changes in the OCR - the rate around which the Reserve Bank transacts with commercial banks - are likely to constitute a more effective means of signaling policy intentions than public comments about prevailing monetary conditions, given the close linkages between the OCR and other short-term interest rates and financial asset prices. Second, the new system is more comparable to that in a number of other advanced economics, and thus is likely to be better understood by financial markets. Third, it is possible that the OCR-based regime will reduce interest rate volatility somewhat, since-in contrast to the "desiredMCI" based regime- there is no longer a presumption for exchange rate shocks to be offset by resets of the OCR, absent a change in projected inflationary pressure 1-2 years hence.

13. The near-term outlook is for continued recovery, subdued inflation, and a slight near-term widening of the current account deficit. Weak terms of trade and supply constraints on agricultural exports will limit the near-term adjustment in the current account, while the import of a navy frigate will boost imports by $1 / 2$ percent of GDP in 1999 . The disappearance of one-off factors on the import side and the lagged impact of the New Zealand dollar's depreciation, should, however, see the external deficit significantly reduced in 2000.

\section{Over the medium term, fiscal consolidation and some recovery in household} saving support the adjustment in the current account and a slow decline in the net external liabilities ratio (Annex I). This scenario does not assume any further adjustment in the exchange rate-indeed, following the 15-20 percent depreciation since mid-1997, the staff's assessment is that the New Zealand dollar is no longer significantly out of line. ${ }^{2}$

${ }^{2}$ Adjusting for the lagged impacts of exchange rate changes through mid-1999, domestic and foreign cyclical positions, and other transitory factors, the underlying current account deficit is 
However, the scenario does assume that - going forward — high household debt levels will constrain consumption growth. If this does not occur with the current configuration of interest and exchange rates and markets subsequently take the view that the path of adjustment is too slow, then further adjustments to exchange rates and/or risk premia would be in prospect.

\section{The Policy Discussions}

\section{At the time of the last Article IV consultation, Executive Directors considered} that the size of New Zealand's external imbalance posed risks, which could be reduced by a tightening of fiscal policies. Directors encouraged early consideration of measures to address demographic pressures on the budget, and structural reforms to raise potential growth.

\section{A. Near-Term Macroeconomic Policies}

\section{Monetary Policy}

16. The authorities considered that the risks around the inflation outlook-which showed CPIX inflation remaining close to the midpoint of the target band over the entire twoyear policy horizon - were evenly balanced, and therefore that no change in the OCR was currently warranted. Although monetary conditions were relatively easy at present, the existence of a significant negative output gap would continue to exert downward pressure on inflation for some time. Conditions were expected to firm gradually over the next two years, by which time the Reserve Bank projected that the output gap would have largely vanished.

\section{The mission agreed that the monetary policy stance was appropriate, and that a} gradual firming of monetary conditions should take place as the output gap narrowed. The appropriateness of the stance was evident not only from the inflation forecasts of the Reserve Bank and others, but also from private sector inflationary expectations, which were now approaching the midpoint of the target range-a signal of the improved credibility of the inflation target. The mission also noted that the current level of the exchange rate would facilitate external adjustment. Finally, the mission welcomed the smooth introduction of the new operating framework in March, and the tighter linkages since that time between the OCR and the rest of the yield curve, as well as the declines in short-term interest rate volatility.

\section{The mission highlighted some risks for monetary policy-and for the economy} more generally -in the period ahead. One such uncertainty related to a possible shift in market sentiment which could exert downward pressure on the currency and push up the risk premium. While the resulting hike in long-term interest rates would dampen inflationary pressure over the 6-8 quarter monetary policy horizon, the accompanying currency depreciation could raise prices in the near term, generating a policy dilemma. The authorities

\footnotetext{
${ }^{2}($...continued $)$ estimated to be $3 \frac{1}{2}$ percent of GDP, consistent with the staff's medium-term projection.
} 
and mission agreed that the policy framework - which implied focusing on the impact of the shock over the 6-8 quarter policy horizon while accommodating some near-term volatility in inflation-provided the solution to this dilemma. What was required was to ensure that inflationary expectations remained anchored near the midpoint of the target range. Once this was achieved, to go further toward maintaining actual inflation near $1 \frac{1}{2}$ percent over shorter horizons would result in excessive output volatility, and thereby do more harm than good.

\section{Fiscal Policy}

19. The 1999/2000 budget targeted operating balance. ${ }^{3}$ While this represented a decline relative to the 1998/99 outturn, one-off factors - as described above-had boosted the surplus last year while a change in accounting practice would reduce the surplus from 1999/2000 on. ${ }^{4}$ Adjusting for these elements, the operating balances in 1998/99 and 1999/2000 were about the same. Furthermore, in both years, modest structural surpluses were being maintained.

\section{The mission considered that the $1999 / 2000$ budget struck a reasonable balance} between the need to support growth in the near term while giving credibility to the authorities' long-term fiscal objectives. First, the target of a balanced budget did not require measures to constrain the operation of the automatic stabilizers and thus possibly endanger the nascent economic recovery. In addition, action had been taken to improve the fiscal position in 1999/2000 by scaling back allowances for additional policy initiatives. ${ }^{5}$ As a result of such measures, an operating deficit was being avoided this year, while the government expenditure ratio was expected to decline. These features would strengthen the credibility of the authorities' commitments to reduce public debt and expenditure over time, and indeed such commitments had been explicitly reaffirmed in the budget. The mission further emphasized that the avoidance of deficit this year would provide a welcome signal to markets that could help to avoid any potential weakening of market sentiment.

21. The authorities had taken decisions on expenditure policy for $2000 / 01$ and 2001/02 which would ensure a path of rising operating surpluses and falling net debt and expenditure ratios. Specifically, the operating balance was expected to rise from about

\footnotetext{
${ }^{3}$ The official budget forecast is for a deficit of NZ $\$ 36$ million ( 0.03 percent of GDP) in $1999 / 2000$, but more recent data suggest that a deficit is likely to be avoided altogether.
}

${ }^{4}$ The change stems from bringing on budget the unfunded liabilities of ACC-the state accident insurance provider-prior to opening up the sector to competition (section IV.D).

${ }^{5}$ New Zealand's budget is fixed in nominal terms from year to year, except for those categories of expenditure - mainly welfare benefits - that are explicitly indexed to the CPI as a matter of law or established policy, or those categories-welfare, health and education funding - that depend on demographic changes in the population. Additional policy initiatives refer to expenditure increases other than due to these CPI- or demographic-related increases. 
zero in $1999 / 2000$ to $1 \frac{1}{3}$ percent of GDP by $2001 / 02$, with government expenditure and net public debt falling to about $331 / 2$ percent and 20 percent of GDP, respectively, over the same period. This was premised on allocations for additional policy initiatives of NZ\$600 million ( 0.6 percent of GDP) in the first year and a similar further amount in the second year.

22. The authorities were prepared to use part of the allocation for policy initiatives to fund tax cuts over the next two years. ${ }^{6}$ Indeed, a third pillar of their fiscal strategyapart from lower public debt and expenditure-was a broad-based low-rate tax system, and personal income tax rates had already been reduced twice since 1996 in support of this pillar. The mission accepted the benefits that could accrue from lower direct tax rates, including better private returns for work and saving efforts. However, it also agreed with the authorities that tax cuts should not compromise other elements of the fiscal strategy, and in particular should not lead to slippages in the envisaged paths of debt reduction or operating surplus increases. This was essential not only to maintain the credibility of the authorities' commitment to fiscal consolidation, but also to prevent any potential weakening of market sentiment that could be engendered by slippages vis-à-vis stated fiscal goals.

23. While the authorities' strategy envisaged an increase in the operating surplus of about 11/3 percent of GDP over the next two fiscal years, the mission saw benefits in overachieving somewhat on this path in order to bolster market confidence further. In this context, it recommended that the allowance for additional policy initiatives in 2000/01 and $2001 / 02$ be scaled back by about $1 / 4$ percent of GDP in each year. Such savings would result in an operating surplus of nearly 2 percent of GDP by 2001/02, and could provide a welcome signal to markets during a period in which the current account deficit was expected to remain at high levels. The authorities saw merit in the mission's position, but noted that achieving such savings would likely require cuts in envisaged policy programs, given that little scope existed for further efficiency gains in the government's operations.

\section{B. External Sector Issues}

24. The magnitude of New Zealand's external imbalance increases the risk of a shift in market sentiment that would raise the risk premium on foreign debt and put downward pressure on the exchange rate. Such risks have been publicly acknowledged by the authorities, and have influenced their policy deliberations, especially on fiscal policy.

25. There is at present, however, no sign of a loss of confidence in New Zealand by foreign investors. Indeed, risk premia - as proxied by the spread between New Zealand and U.S. ten-year government bond yields-have fallen to 50-75 basis points during 1998-99, compared to 400 basis points in the early 1990 s and 150 basis points at mid-decade. In addition, the private sector has retained ready access to foreign financing.

${ }^{6}$ In other words, some portion (or all) of the NZ\$600 million could be used to reduce taxes rather than increase expenditure, with a neutral impact on the operating balance. 
26. Moreover, several factors are serving to limit the potential costs of exchange rate and interest rate movements brought on by a potential future adverse shift in market sentiment. The following five factors may be especially relevant (see also Box 3 ).

27. First, the economic impact of exchange rate and interest rate shocks would be limited by a number of factors. Reflecting the extended period with a floating exchange rate and volatile interest rates, banks are well hedged against movements in exchange rates and interest rates, while nonbank corporates are also well hedged against exchange rate movements. The prevalence of foreign-currency risk hedging is confirmed by a recent official survey covering the bulk of short-term foreign-currency debt. In addition, stress tests on bank portfolios - the results of which are mandatorily published in banks' quarterly disclosure statements - confirm that banks carry very little exchange rate or interest rate risk on their balance sheets. Finally, the pronounced exchange rate and interest rate cycles of the past two years-when the currency depreciated by some 20 percent from mid-1997 to mid-1998 while interest rates were maintained near double-digit levels in early 1998 before coming off by half in the course of the year-and the recession, provide direct evidence of the robustness of the private sector to the type of shocks that could be expected if market sentiment shifted.

28. Second, banks are in a financially strong position at present-with capital ratios well above the statutory Basle minima and very low levels of impaired assets-which enhances their resilience to potential future shocks. Capital presently accounts for about 10 percent of risk weighted assets, while impaired assets comprise only about $1 / 2$ percent of portfolios-down from about 9 percent at the beginning of the decade. Banks, moreover, do not appear to face significant risks of a sharp fall in asset prices in the future, given the poor performance of the domestic equity market and the leveling-off of house prices in recent years. While household mortgages constitute about half of bank lending, default rates on home mortgages have historically been very low in New Zealand, including in periods of high interest rates. Moreover, despite high levels of household debt, households maintain a strong net worth position, with financial assets exceeding the value of financial liabilities.

29. Third, were portfolio preference to shift, a sizable proportion of short-term external debt would likely not be subject to rollover risk. This is because some two-thirds of short-term external debt is owed by banks, which are virtually entirely foreign-owned in New Zealand. The strong financial position and international reputation of the foreign parents, together with the relatively small proportion of global assets accounted for by the New Zealand subsidiaries' operations, reduces the likelihood that New Zealand banks would face difficulty rolling over credits. Rollover risk may be reduced more generally because about half of total private sector external debt is between related parties, i.e., the creditor has an equity interest in the borrower which is greater than 25 percent.

30. Fourth, the central bank is unlikely to get into the sort of difficulties encountered in a number of crisis countries where intervention was used to sustain the exchange rate at artificial levels. Indeed, New Zealand has not intervened in the foreign exchange market 


\section{Box 3. New Zealand: External Exposure}

- As at end-March 1999, New Zealand's external debt amounted to NZ\$101.9 billion, about 100 percent of GDP, a slight increase over the previous year, but noticeably higher than at mid-decade, when total external debt amounted to NZ\$70.0 billion (81 percent of GDP). The increase in external debt reflects the cumulation of current account deficits since mid-decade, which have averaged nearly 5 percent of GDP per year.

- Most external debt is held by the private sector, reflecting the fact that the government has been running surpluses since mid-decade that have been used to pay down public debt. In addition, the public sector has no net foreign currency exposure, as foreign-currency assets and liabilities are perfectly matched. Finally, there is no publicly-guaranteed private external debt in New Zealand.

- Short-term external debt amounted to NZ\$43.8 billion at end-March 1999, representing 43 percent of total external debt. This proportion is slightly higher than in 1998, but lower than in the mid-1990s, and is also lower than the average proportion among industrial countries. The bulk of short-term external debt is owed by banks, which are themselves foreign-owned.

- Half of New Zealand's external debt is denominated in New Zealand dollars, and is thus not subject to foreign currency risk; at the same time, the significant local-currency proportion of foreign debt reduces the potential adverse impact of a depreciation of the New Zealand dollar on debt service. In addition, based on a survey covering some three quarters of outstanding foreign-currency external debt, virtually all foreign-currency denominated external debt is hedged against exchange rate movements, mainly through the use of financial derivatives products and to a lesser extent through "natural" hedges (see Table below).

- Given extensive foreign ownership of New Zealand's banks and the prevalence of multinational corporations in New Zealand's corporate sector, nearly half of New Zealand's external debt is between related parties, i.e., where the creditor has a greater-than -25 percent equity interest in the debtor.

New Zealand: Structure of External Debt

(In billions of New Zealand dollars; at end-March)

\begin{tabular}{|c|c|c|c|}
\hline & 1995 & 1998 & 1999 \\
\hline Total external debt & 70.0 & 99.6 & 101.9 \\
\hline \multicolumn{4}{|l|}{ By sector } \\
\hline Public & 23.4 & 20.0 & 17.4 \\
\hline Private & 46.6 & 79.6 & 84.6 \\
\hline Related company & 22.2 & 42.3 & 45.2 \\
\hline \multicolumn{4}{|l|}{ By maturity 1/ } \\
\hline Long-term & 34.8 & 55.7 & 53.3 \\
\hline Short-term & 33.3 & 40.9 & 43.8 \\
\hline Unallocated & 1.9 & 2.9 & 4.9 \\
\hline \multicolumn{4}{|l|}{ By currency composition } \\
\hline Local currency & 30.9 & 53.8 & 48.3 \\
\hline Foreign currency & 39.1 & 43.0 & 48.8 \\
\hline \multicolumn{4}{|l|}{ By hedging instruments $2 /$} \\
\hline Financial derivatives & $\ldots$ & 17.6 & 24.5 \\
\hline Naturally hedged & $\ldots$ & 13.2 & 12.4 \\
\hline Unhedged & $\ldots$ & 1.7 & 1.1 \\
\hline Unallocated & 1.9 & 2.9 & 4.9 \\
\hline
\end{tabular}


since 1985, even in periods of sharp exchange rate pressures. This pure floating approach is well understood by market participants, and implies that potential speculators would not expect the central bank to take the other side of any positions they might wish to acquire. ${ }^{7}$

31. And fifth, the transparency of the policy and regulatory frameworks would be expected to bring forward any economic adjustments that needed to take place. This would generally tend to reduce the severity of the adjustments themselves.

\section{While these factors mitigated the degree of external vulnerability, the mission} pointed out that, were sentiment to shift, some adverse effects on the economy would be unavoidable. First, while stress tests showed little effect on banks of even sizable exchange and interest rate shocks, a sustained rise in interest rates would be expected to adversely affect the corporate sector, and thereby credit risk of local banks. In addition, direct borrowing costs in international markets by nonbank corporates-which are the major holders of long-term external debt in New Zealand-would also be affected by a rise in the risk premium; such a rise could be precipitated, for example, by policy uncertainties in the runup to this year's elections, or by a further downgrading in New Zealand's credit rating by a major rating agency. ${ }^{8}$ Second, market participants acknowledged the buildup of significant short currency positions by highly-leveraged institutions in the course of 1998, with the aggregate level of positions perhaps peaking somewhere close to 10 percent of GDP or one third of daily market (spot plus forward) turnover. While it was impossible to determine the independent effect of such positions on the exchange rate, there is certainly potential for future buildups to cause abrupt exchange rate and/or interest rate movements.

\section{To underpin market confidence, the mission stressed the importance of} maintaining a strong fiscal policy - as discussed above-and of measures to remove potential disincentives to private saving. It viewed positively the authorities' approach to reducing the high level of welfare dependency and curtailing the generosity of the state pension system. It recommended consideration of further reforms in these two areas, as well as with respect to tax reform where changes that could improve the outlook for private saving also appeared worthy of consideration (see section IV. D below).

${ }^{7}$ The pure floating approach also reduces the relevance of the reserves/short-term debt ratio (17 percent in March 1999; see Table 2) as a vulnerability indicator, given the low probability that reserves would be used to support the currency. In any case, this ratio is higher than the average ratio among industrial countries with floating exchange rates and its interpretation should take into account that about two-fifths of New Zealand's short-term external debt is denominated in New Zealand dollars.

${ }^{8}$ Moody's downgraded New Zealand's credit rating late last year, while Standard \& Poor's adjusted its outlook from stable to negative at about the same time; both cited vulnerabilities associated with New Zealand's external imbalance as having influenced their decisions. 


\section{Long-Term Fiscal Issues}

\section{As in a number of other industrial countries, New Zealand will experience a} substantial ageing of its population which will contribute to significant pressures on the fiscal position beginning in about 2010. Demographic projections suggest that the old-age dependency ratio will more than double over the next forty years, contributing to a sharp increase in health- and pension-related public expenditure. Official projections contained in the latest Fiscal Strategy Report suggest that noninterest expenses of the government-under a 'medium-expense scenario' (MES) - could rise to about 42 percent of GDP over the next fifty years, some 12 percent above the government's current long-term target for total expenses. Projections undertaken by the World Bank and by Fund staff (see SM/97/262) give similar results, suggesting that expenses on health and pensions would about double during the first half of the next century, from their current combined level of about 12 percent of GDP.

\section{The authorities are considering various options to address looming demographic} pressures on the budget. At issue is both the level of expenses that needs to be fundedincluding whether further reforms to the health and pension systems are desirable - and the approach to funding, that is whether to increase public saving further in the medium term to build up sufficient reserves to prefund long-term expenses without tax increases, or alternatively fund the increase in expenses by tax/spending measures down the road.

\section{While final decisions were not expected in the near term, fiscal policies have} nevertheless been set with the pressures resulting from population ageing in mind. First, the intention to reduce government expenditure to below 30 percent of GDP before the longterm pressures emerge will reduce the need for other measures in the future. And second, recent decisions to reduce the generosity of the state pension system (NZS) - by raising the retirement age and reducing payouts ${ }^{9}$-will lower long-term budgetary expenses on pensions. In addition, an official task force was undertaking a study of the options for possible future reform of NZS-including income/asset testing; further changes in the retirement age; and payout levels-and was due to report next year.

37. The mission recommended that, pending final decisions on possible future health and pension reform and on the approach to funding, fiscal policy over the medium term target continued expenditure control and the buildup of somewhat larger operating surpluses than were envisaged through 2001/02, as described for example in the latest Fiscal Strategy Report's "central scenario". The reasons were threefold. First, such a scenario would be consistent with achieving the authorities' stated long-term objective for government expenditure within a decade or so, while a slower pace of expenditure control could raise questions about the likelihood of ever achieving it, and thereby undermine credibility. Second,

\footnotetext{
${ }^{9}$ The retirement age is being raised to 65 in steps, while a decision was taken last year to alter the indexation rule-essentially reducing the threshold from which pensions would be indexed to wages rather than prices - which will reduce payouts gradually beginning in 1999/2000.
} 
continued expenditure control and rising operating surpluses would be a prudent course to follow pending a consensus being reached on whether and how to reform the pension and health systems. And third, with the current account deficit likely still to be at high levels in three years, a path of rising budget surpluses beyond the three-year policy horizon would help to reduce external vulnerability by bolstering market confidence and underpinning external adjustment. The authorities saw merit in these arguments, but felt that the scope to reduce taxes over the next decade would nevertheless grow as operating surpluses reached significant levels and net debt came down.

\section{Structural Reform and Productivity Growth}

38. Productivity growth-the excess of output over input growth-was very poor in New Zealand in the 1970s and early 1980s, but picked up during the 1990s (Box 4). A major study commissioned by the authorities suggests that productivity (TFP) growth was actually negative during $1972-84$, a period coinciding with high assistance to industry and a heavily-regulated economy. In the second half of the 1980s, TFP growth was about zero, possibly reflecting adjustment costs engendered by reform-including capital scrapping and "learning" how to operate in the new, deregulated, environment. From 1993 on, however, productivity growth rose to $1 \frac{1 / 2}{2}$ percent a year (somewhat above the median performance of industrial countries), as adjustment costs to the new regime subsided while the implementation of more recent reforms-including labor market deregulation-began to bear fruit.

39. The authorities considered that the improved performance in the 1990 s probably was due in part to structural reforms, but that it was difficult to be confident about precisely how large the payoff from reform had been. Measurement issues made the calculation of TFP somewhat problematic, and the achievement of higher productivity growth since 1993 was likely also partly due to cyclical factors, which would imply that trend TFP growth might be below $1 \frac{1}{2}$ percent. Looking forward, the authorities and mission agreed that the structural reform agenda was likely to yield further benefits over time.

40. First, human capital development remains a key pillar of the authorities' growth strategy. Both at the school and tertiary levels, the authorities had put in place reforms aimed at boosting competition, giving students more choice, and providing more autonomy about how institutions deploy their funding. The mission endorsed these efforts, which were expected to encourage a performance culture in public schools while further boosting participation rates at the tertiary level. Looking forward, the challenge was to ensure that the present low skill base of the labor force-as compared with other industrial countries-rose sufficiently over time so that skills would be available to sustain into the medium term the improved productivity performance of the 1990s. In this regard, it was agreed that immigration policy - by increasing the emphasis on the skill mix of migrants - could prove a useful adjunct to education policy in improving the quality of the workforce. 
Box 4. Productivity and Potential Growth

- According to a major recent study, ${ }^{1}$ New Zealand's annual trend total factor productivity (TFP) growth rate averaged minus 0.4 percent during 1972-84, about zero during 1984-93, and then picked up to 1.5 percent during 1993-98. This pattern of productivity growth is consistent with a favorable long-term impact of structural reforms on productivity growth, but one in which shortterm adjustment costs- together with delays in some reforms (e.g., labor market deregulation) until more recently - caused the benefits of reform to be postponed by several years.

- The recent pickup in TFP growth, however, may be partly affected by cyclical factors. In particular, the 1993-98 period accounts for the 1993-95 upswing but does not fully capture the recession in 1998 (the sample used in the study ended in March 1998). When using a more cyclically-neutral period (the 1990s as a whole, for example), the study's results indicate that TFP growth averaged 1.1 percent (about the median performance for industrial countries).

- The study also estimated labor productivity growth rates, which have averaged 1.5 percent during the $1990 \mathrm{~s}$, or about $1 \frac{1}{2}$ times the estimated TFP growth rate. ${ }^{2}$

- Future potential growth will depend on labor productivity and labor force growth. Assuming that labor productivity will continue to increase at a rate of $1 \frac{1}{2}$ percent per year and using Statistics New Zealand labor force projections, the potential growth rate should be about $2 \frac{1}{2}$ percent per year over the next 7-8 years. This would also be consistent with some slowdown in TFP growth (to about 1 percent) in comparison to the 11/2 percent rate observed during 1993-98.

- An additional measure of productivity is the marginal product of capital (MPK), which is an indicator of the efficiency of investment (in case past investment rates were excessive, the capital-output ratio would increase and the MPK would tend to fall). According to staff estimates, the MPK in New Zealand has been relatively stable in recent years, and similar to the level in other advanced economies (e.g., Australia and the United States). Thus, the evidence on MPK would not indicate that investment in New Zealand has been either insufficient or inefficient.

${ }^{1}$ D. Lawrence and L. Diewert, "Measuring New Zealand's Productivity", March 1999. The study has several advantages over previous efforts to estimate New Zealand's growth performance, including development of a consistent data set covering some 60 outputs and inputs valued at producer prices.

${ }^{2}$ Using a growth accounting framework, it is easy to show that in a mature economy, with a constant capital-output ratio and capital income share of about one-third, labor productivity growth will be about 50 percent higher than TFP growth. 
41. Second, further deepening competitive forces within the economy was also a key pillar of the authorities' structural reform/growth effort. This was being achieved both by opening the economy further to external competitive pressures and by taking some initial steps toward deregulation of the agricultural producer boards. On the trade side, the authorities had moved in mid-1998 to eliminate automobile tariffs, while tariffs in the other more heavily protected sectors - textiles, clothing, and footwear-would be reduced to zero in steps through 2006, with all other tariffs zero by $2002 .^{10}$ The mission endorsed these steps, which would eliminate all import tariffs well ahead of the deadline established under the APEC framework for advanced-economy members. As regards the monopoly agricultural producer boards, the authorities had made public their position that removal of the statutory backing for all New Zealand's producer boards is inevitable, and requested last year that the boards form plans of how they will operate without such backing. The authorities and mission agreed that the goal of deregulation must be a structure that allows producers to receive clear price signals for their product and investments, while fostering innovation and growth in a sector that still constitutes a significant portion of the economy's output and export base. ${ }^{11}$

\section{Third, the authorities were taking steps to enhance the economy's growth} potential by improving incentives for labor force participation. The authorities had taken a number of recent steps to reduce welfare dependency, in recognition that the level of such dependency - about 13 percent of the working-age population receives welfare benefits as their major income source-is both a significant burden on the budget and detrimental to the maintenance of workforce attachments. Key recent steps include: increased emphasis on active case management; changes in benefit abatement rates to encourage part-time work; and more extensive application of work testing to encourage both part-time and full-time work. The mission supported such efforts, both in order to raise labor force participation and to sharpen saving incentives which may have been dulled by the extent of social insurance provided by New Zealand's welfare benefit programs. Finally, the authorities had also recently moved to introduce competition into the state-run system of accident insurance. The new system was expected to yield a number of benefits, including greater incentives for rehabilitation outcomes for long-term beneficiaries of the system; in this context, recent data were encouraging, as exits of such beneficiaries had posted a sharp increase since mid-1998.

43. Fourth, the mission recommended consideration of further reforms in the tax and pension systems as a way to remove potential disincentives for private saving, and thereby lessen the external pressures that might arise with more rapid growth. As regards the tax system, the share of tax revenue collected through direct taxation in

\footnotetext{
${ }^{10}$ The average tariff rate was about 4 percent in 1998 and New Zealand imposes no nontariff barriers for industry-protection purposes.

${ }^{11}$ Since the conclusion of the consultation discussions, restructuring proposals for the dairy, kiwifruit, and apple and pear boards have been introduced into Parliament, with removal of the dairy board's statutory backing being phased in from September 2000 under the proposal.
} 
New Zealand-about two thirds - is relatively high by industrial-country standards. ${ }^{12}$ While supporting the authorities' efforts to reduce the direct tax burden over time provided this did not conflict with other fiscal objectives, the mission pointed out that the positive impact on private saving could be accelerated by a revenue-neutral tax-mix switch in favor of indirect taxes. The authorities cautioned that achieving revenue neutrality could prove difficult, as budgetary effects would depend on policy decisions regarding the indexation of welfare benefits, which would be controversial. Regarding pension reform, the mission recommended that - apart from fiscal considerations - the authorities take account of potential disincentives to private saving in deciding the nature of future reforms, given that the current system likely discouraged self-provision for retirement in New Zealand (SM/97/262).

\section{STAFF APPRAISAL}

44. New Zealand was faced with a difficult set of economic challenges during 199798_-including recession in key Asian export markets and severe drought-but economic outcomes were nonetheless relatively favorable. While the economy experienced recession in the first half of last year, a recovery was underway by the second half and has now gathered momentum. Other factors, including low inflation and the absence of distress in either the corporate or financial sectors - despite both the sizable depreciation of the New Zealand dollar and high real interest rates in the first part of last year-are further testimony to the economy's resilience under adverse circumstances. This resilience is itself a key payoff from 15 years of economic reform that has completely transformed the New Zealand economy.

45. This said, New Zealand continues to face some difficult economic challenges. Of these, the staff would highlight two that warrant the continued attention of policy makers: first, the vulnerabilities associated with the large external deficit and debt; and second, the need to sustain the recent improvement in productivity growth and thereby reverse the decline in New Zealand's per capita income position among industrial countries.

46. Near-term policies are broadly appropriate in light of the external sector risks. The relatively easy level of monetary conditions - especially the fall in the New Zealand dollar since mid-1997 — combined with the authorities' intention to adhere to a path of rising budgetary surpluses through 2001/02, should help to support external adjustment without unduly compromising the economic recovery. As the output gap narrows over the next two years, some firming of monetary conditions will be appropriate in order to maintain inflation near the midpoint of the authorities' target band.

47. Monetary policy may nevertheless be faced with a number of shocks in the period ahead, including a possible shift in market sentiment which exerts downward

\footnotetext{
${ }^{12}$ This share has been reduced from about three-quarters in the mid-1980s as a result of the GST's introduction. A study undertaken by the staff (SM/97/262) found a positive impact on household saving from reducing the share of revenue collected in the form of direct taxes.
} 
pressure on the currency and pushes up the risk premium. In these circumstances, the authorities should continue to be guided by their monetary policy framework, which would imply focusing on the impact of such shocks on inflation over the 6-8 quarter policy horizon, while accommodating some near-term volatility in inflation. Were the shocks to leave inflationary pressure over the policy horizon, and inflationary expectations, largely unchanged, no policy change would be called for. A less flexible approach that attempted to maintain actual inflation near the midpoint of the target range over shorter horizons would likely do more harm than good, by exacerbating output and interest rate volatility.

\section{Near-term fiscal policy should also continue to be set with external sector risks,} and long-term fiscal objectives, in mind. In this regard, the staff would emphasize the importance of avoiding a budget deficit this fiscal year, and of gradually building up surpluses over the subsequent two years, both in order to enhance the credibility of the authorities' commitment to their stated long-term fiscal objectives for expenditure and debt, and in order to bolster market confidence during a period in which the current account deficit is expected to remain at very high levels. Indeed, in the staff's view, there would be benefits from both these vantage points in overachieving somewhat on the authorities' fiscal plans by scaling back the allowance for additional policy initiatives over the next two years in order to achieve a fiscal surplus of about 2 percent of GDP by 2001/02. In any event, the staff would recommend that tax cuts be eschewed altogether over the next two years, unless they are offset by other measures that prevent any slippages in the envisaged paths of the budget surplus or net debt.

49. Over the medium term, New Zealand-like a number of industrial countrieswill need to address the budgetary pressures stemming from population ageing. It is important to begin now to address these issues, because a solution involves complex social and economic considerations, and requires building consensus to ensure that the chosen course is adhered to over time. The staff welcomes the authorities' active consideration of these issues, including through the work of the superannuation task force, which will evaluate the need for further pension reform and alternative approaches to funding long-term expenses.

\section{The staff would see merit in a course that involved continued expenditure} control and the buildup of somewhat larger operating surpluses over the medium term than are envisaged for the period through 2001/02, as in the "central scenario" in the latest Fiscal Strategy Report. The reasons are threefold. First, such a strategy would be consistent with achieving the authorities' long-term objective for government expenditure within a decade or so, while a slower pace of expenditure control could raise questions about the likelihood of ever achieving it, and thereby compromise fiscal credibility. Second, continued expenditure control and rising operating surpluses would be a prudent course to follow pending a decision on future pension and health care reform. And third, staying the course embodied on fiscal consolidation would help to underpin market confidence during a period in which the current account deficit is expected to remain at very high levels. 
51. As regards the degree of external vulnerability, the staff considers that the economy is relatively well positioned to absorb exchange rate and interest rate shocks associated with a possible future shift in market sentiment, but nevertheless cautions that some adverse effects should be expected if these shocks occurred. To minimize these risks, the authorities need to maintain a strong set of macroeconomic policies-especially, as noted above, fiscal policy. In addition, the staff would suggest that active consideration be given to other measures that could underpin market confidence and external adjustment over the medium term. In this context, the staff endorses efforts in train to reduce welfare dependency and the generosity of the state pension scheme, both of which are likely to improve the environment for private saving in New Zealand by encouraging self-provision for retirement and reducing a possibly excessive degree of social insurance provided by the welfare system. In addition, it would advise further consideration of tax reforms to remove potential disincentives to private saving, including those associated with the still relatively high proportion of revenue levied through direct taxes.

52. The staff strongly supports the authorities' structural reforms aimed at boosting the economy's sustainable growth potential, and believes that steady adherence to the main elements of the reform agenda will continue to yield further benefits.

53. First, with regard to human capital development, education reforms at both the school and tertiary levels - by giving students more choice and learning institutions more autonomy - should help to improve the skill level of the workforce. Going forward, the challenge will be to ensure that New Zealand's present relatively low skill base rises sufficiently over time to sustain the recent improvement in productivity growth, by continually monitoring the impact of reforms, and making further adjustments where appropriate.

54. Second, regarding competition, New Zealand's commitments to eliminate tariffs completely by 2006 -including in the still heavily protected sectors of textiles, clothing, and footwear-is a crucial step in fully subjecting the economy to international competitive forces. The staff also welcomes the authorities' efforts to reduce distortions resulting from the presence of monopoly agricultural producer boards, including through removal of the boards' statutory backing. The goal must be to put in place a structure that allows producers to receive clear price signals for their product and investment, while fostering innovation and growth in a sector that still constitutes a large share of the economy's output and export base.

\section{Third, the staff supports efforts underway to strengthen New Zealanders'} attachment to the workforce inter alia by reducing welfare dependency. The emphasis being placed on active case management, lowering abatement rates, and more extensive work testing, should help to encourage welfare beneficiaries to take on productive work assignments, and thereby improve the economy's growth potential over time.

56. New Zealand publishes an array of high-quality economic and financial statistics that are adequate for surveillance. The staff supports the authorities' efforts to improve the 
frequency and timeliness of balance of payments data in order to improve monitoring of the external financing of the current account deficit. As regards Y2K issues, New Zealand would appear to have a relatively high level of preparedness in key sectors-including the public sector, the financial sector, telecommunications, energy, and transportation-while the staff supports efforts underway to upgrade preparedness among small- and medium-sized firms.

57. It is proposed that the next Article IV consultation with New Zealand take place on the standard 12-month consultation cycle. 
FIGURE 1

NEW ZEAL.AND

SELECTED REAL ECONOMIC INDICATORS, 1994-1999
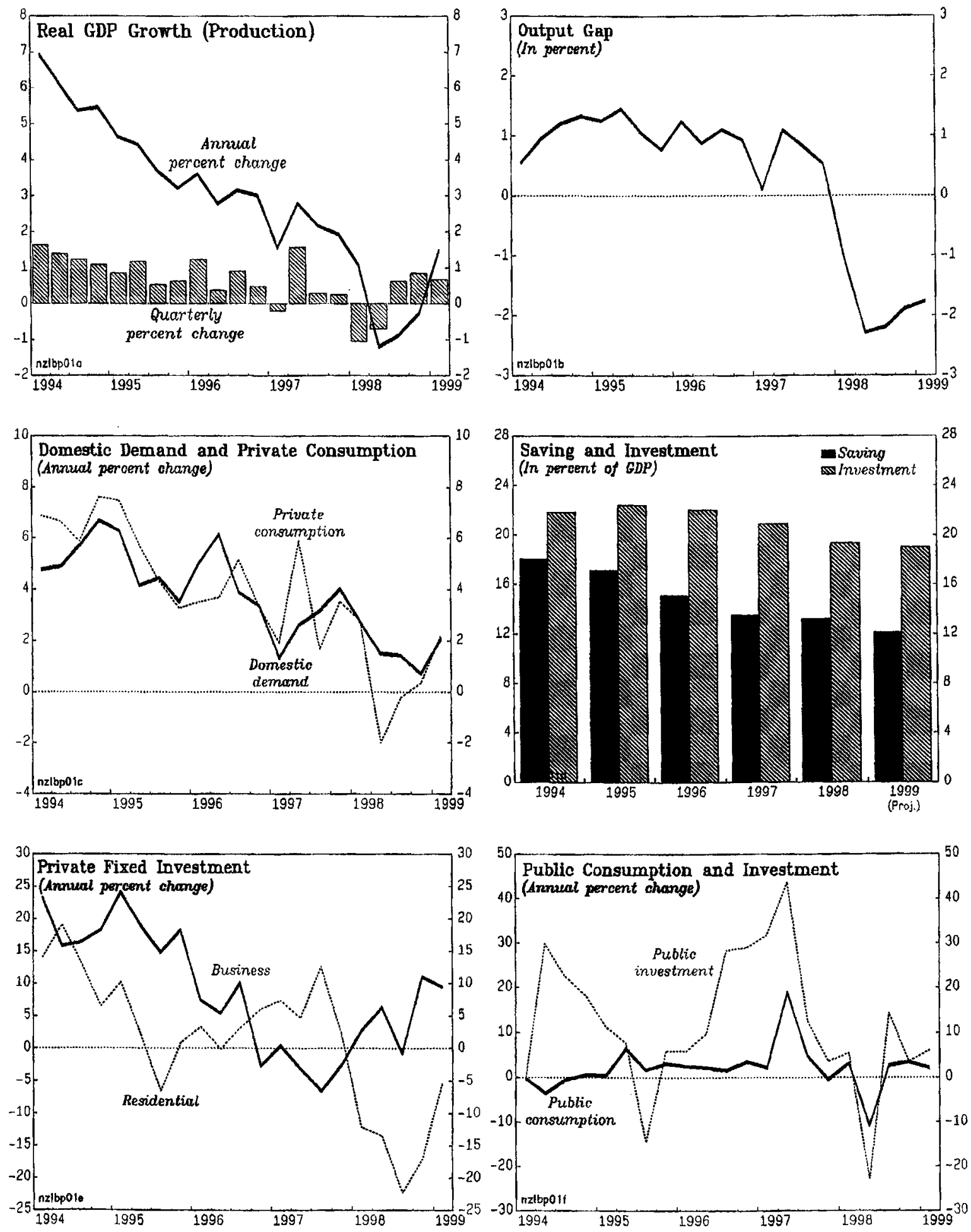

Sources: Statistics New Zealond; and staff estimates. 
FIGURE 2

NEW ZEALAND

MONETARY AND FINANCIAL INDICATORS, 1994-1999
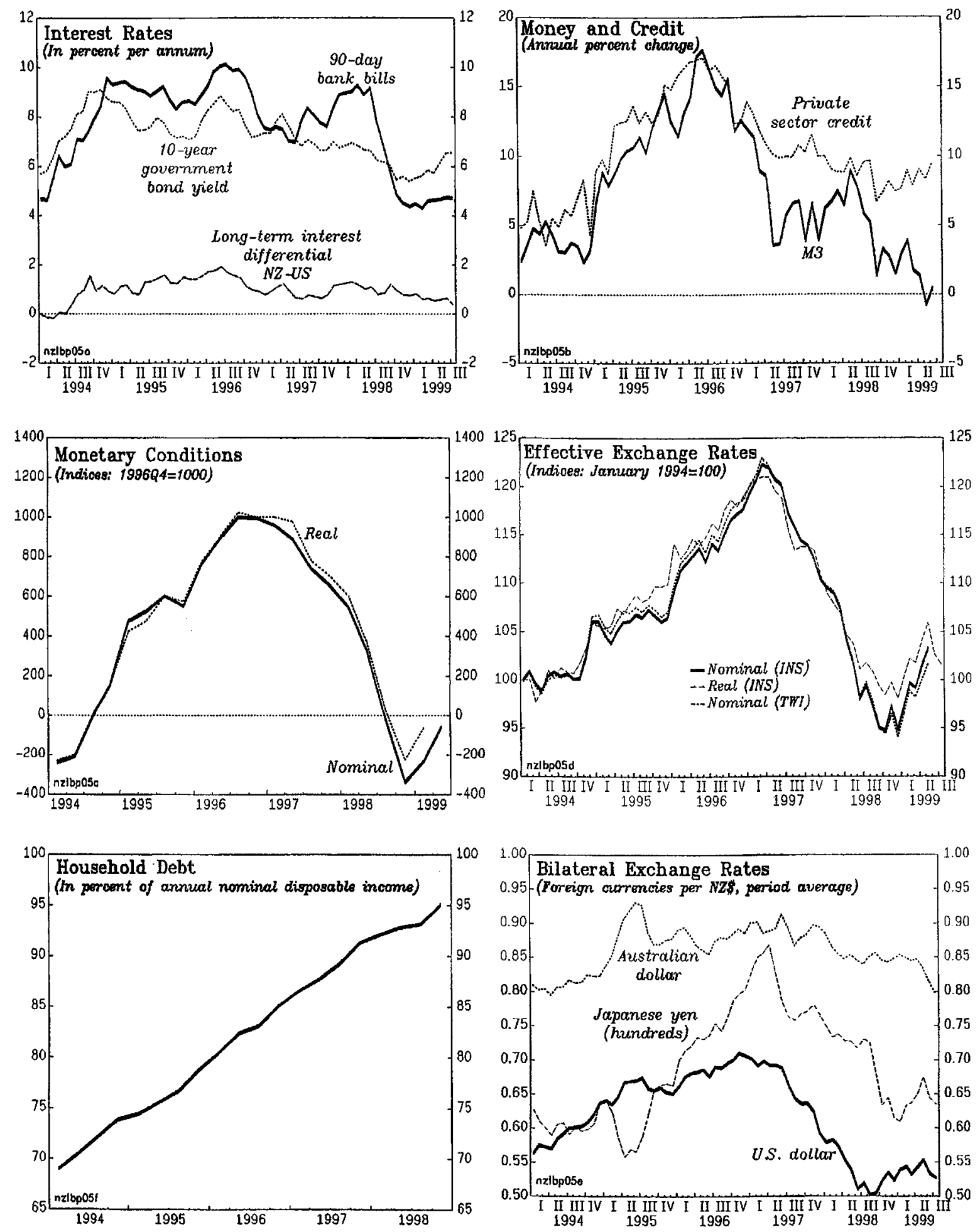

Sources: Reserve Bank of New Zealand; and IMF, International Financial Statistics. 
FIGURE 3

NEW ZEALAND

BALANCE OF PAYMENTS AND EXTERNAL INDICATORS, 1994-1999

(Annual percent of GDP, unless otherwise noted)
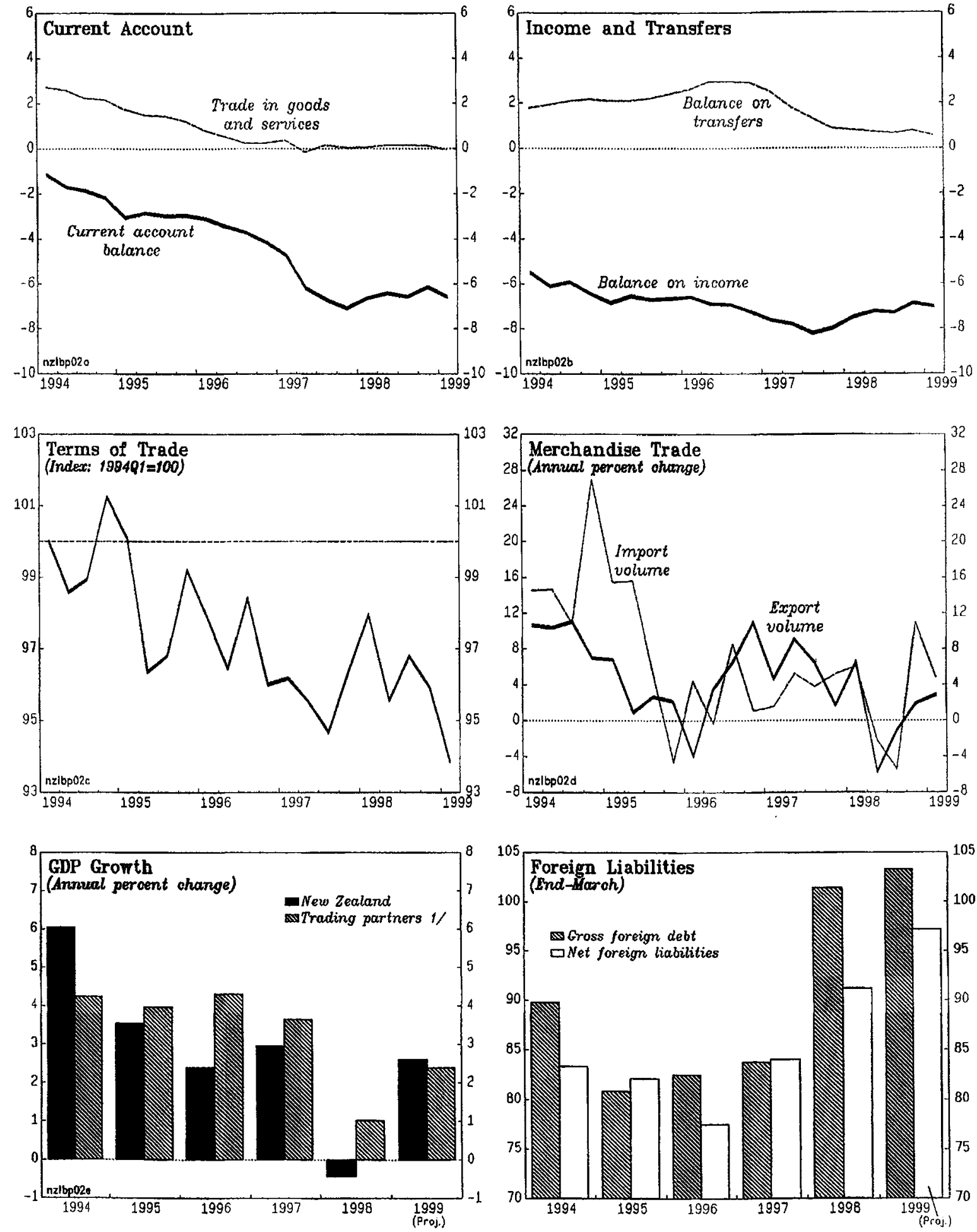

Sources: Statistics New Zealand; IMF, World Economic Outlook; and stoff estimates.

1/ Export-weighted average based on data for partner countries that occount for at least 95 percent of trade of New Zealand. 
FIGURE 4

NEW ZEALAND

FISCAL INDICATORS, 1993/94-1999/2000

(In percent of GDP)
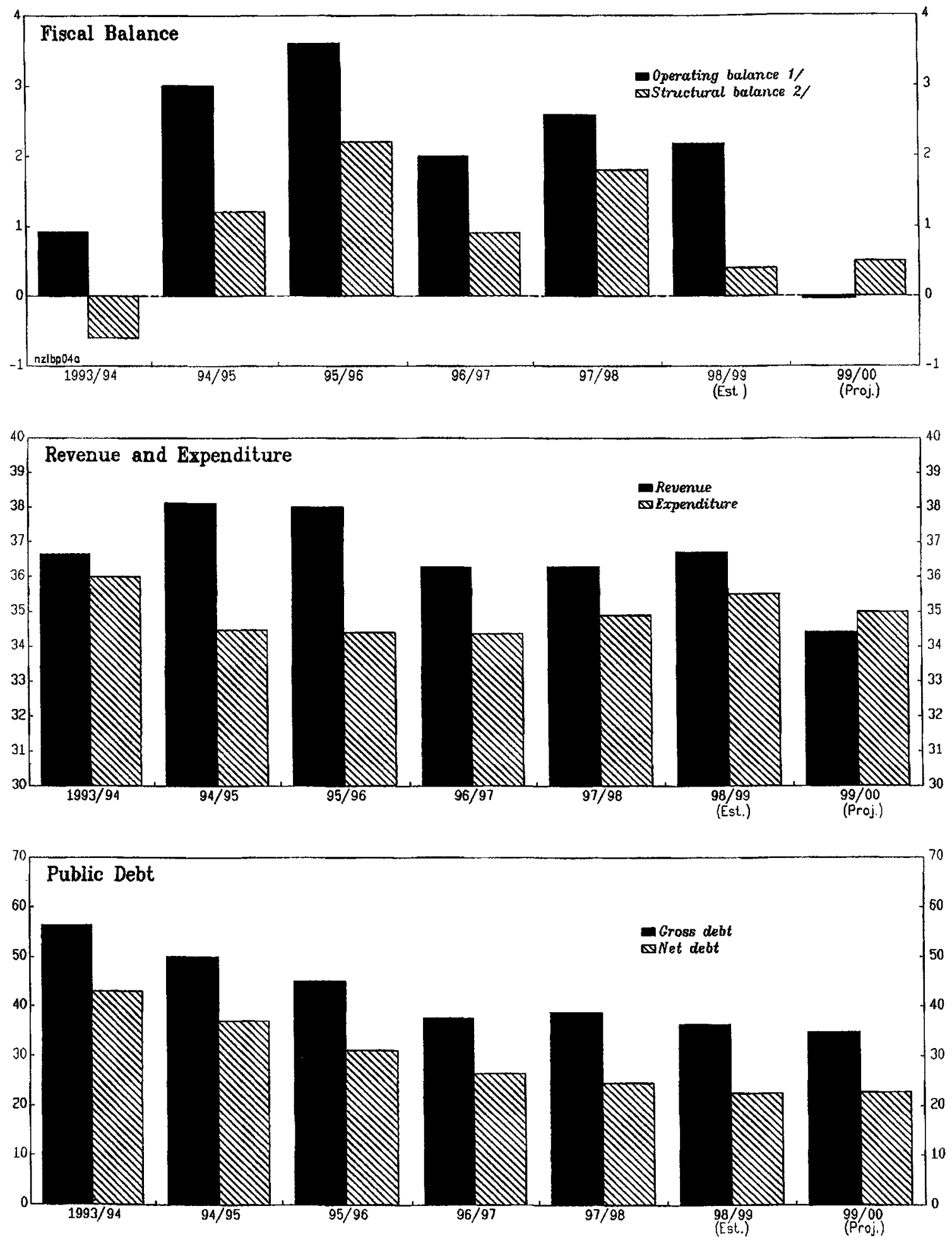

Sources: Data provided by the New Zealand authorities; and staff estimates.

1/ Equals revenue less expenditure plus net surplus from SOEs and Crown entities. 2) Staff estimates. 
FIGURE 5

NEW ZEALAND

LABOR MARKET AND INFLATION INDICATORS, 1994-1999

(Annual percent change, unless otherwise noted)
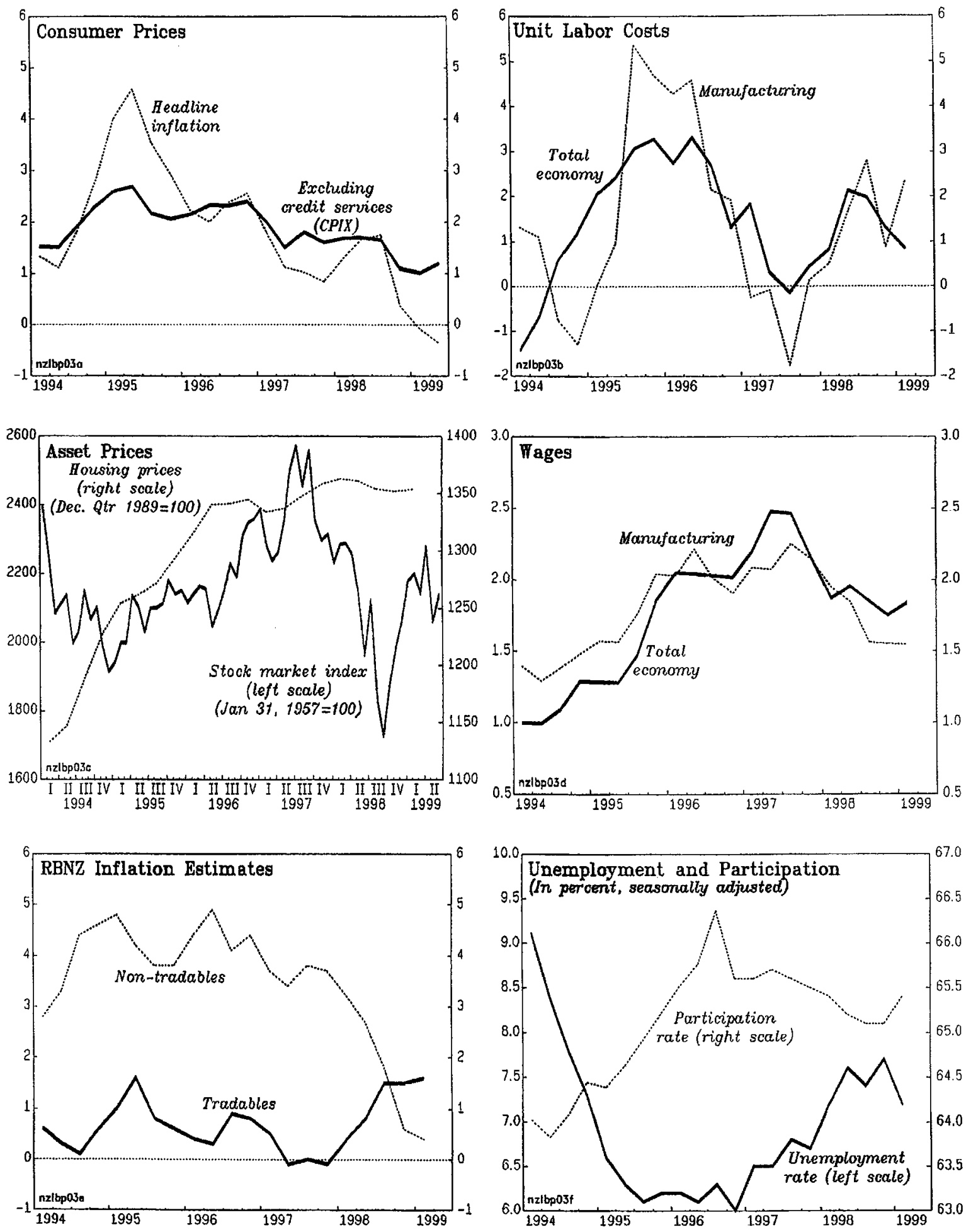

Sources: Statistics New Zeoland; and staff estimates. 
Table 1. New Zealand: Selected Economic and Financial Indicators, 1995-2000

$\begin{array}{ll}\text { Nominal GDP (1998): } & \text { US\$ } 52.71 \text { billion } \\ \text { Population (1998): } & 3.79 \text { million } \\ \text { GDP per capita (1998): } & \text { US\$ 13,908 } \\ \text { Quota: } & \text { SDR } 894.6 \text { million }\end{array}$

\begin{tabular}{|c|c|c|c|c|c|c|c|}
\hline & \multirow[b]{2}{*}{1995} & \multirow[b]{2}{*}{1996} & \multirow[b]{2}{*}{1997} & \multirow[b]{2}{*}{1998} & \multicolumn{3}{|c|}{ Proj. } \\
\hline & & & & & 1999 & & 2000 \\
\hline \multicolumn{8}{|l|}{ Real growth (percent ehange) } \\
\hline GDP (production basis) & 4.0 & 3.1 & 2.1 & -0.3 & 2.6 & & 3.3 \\
\hline Domestic demand & 5.1 & 3.9 & 3.2 & 0.2 & 3.9 & & 2.8 \\
\hline Private consuruption & 4.6 & 4.6 & 2.8 & 1.6 & 2.7 & & 2.5 \\
\hline Fixed investment & 12.2 & 6.2 & 2.7 & -1.1 & 5.1 & & 5.6 \\
\hline Exports of goods and services & 3.8 & 3.5 & 2.9 & 1.5 & 5.6 & & 6.1 \\
\hline Imports of goods and services & 9.1 & 8.2 & 4.0 & 2.8 & 7.6 & & 4.4 \\
\hline CPI excluding credit services (percent change) & 2.4 & 2.3 & 1.7 & 1.5 & 1.3 & & 1.9 \\
\hline Unomployment rate (in percent) & 6.3 & 6.1 & 6.6 & 7.5 & 7.2 & & 7.0 \\
\hline \multicolumn{8}{|l|}{ Investment and saving (in percent of GDP) } \\
\hline Investment & 22.4 & 22.0 & 20.9 & 19.3 & 19.0 & & 19.7 \\
\hline National saving $1 /$ & 17.1 & 15.1 & 13.5 & 13.2 & 12.1 & & 13.6 \\
\hline Privato saving & 11.2 & 9.0 & 8.5 & 8.3 & 8.9 & & 8.8 \\
\hline Public saving & 5.9 & 6.1 & 5.3 & 4.2 & 3.3 & & 3.8 \\
\hline \multicolumn{8}{|l|}{ Public finanes (in percent of GDP) $2 J$} \\
\hline Revenue & 38.1 & 38.0 & 36.3 & 36.3 & 36.7 & & 34,4 \\
\hline Expenditure & 34.5 & 34.4 & 34.4 & 34.9 & 35.5 & & 35.0 \\
\hline Operating balance $3 /$ & 3.0 & 3.6 & 2.0 & 2.6 & 2.2 & & 0.0 \\
\hline Adjusted operating balance $4 /$ & 2.0 & 3.0 & 1.5 & 1.7 & -0.3 & & 0.0 \\
\hline Net pubtic debt & 36.9 & 31.0 & 26.4 & 24.5 & 22.5 & & 22.7 \\
\hline \multicolumn{8}{|l|}{ Monoy and credit (end of period) } \\
\hline M3 (percent change) & 14.5 & 12.6 & 3.9 & 1.5 & 0.6 & $5 I$ & $\ldots$ \\
\hline Pivate domestic credit (percent change) & 15.1 & 12.4 & 10.0 & 7.5 & 9.5 & $5 /$ & $\cdots$ \\
\hline Interest rate (90-day, in percent) & 8.6 & 8.1 & 8.3 & 4.4 & 4.7 & $6 !$ & ... \\
\hline Government bond yield (10-year, in percent) & 7.2 & 7.2 & 7.0 & 5.4 & 6.6 & 6 & $\ldots$ \\
\hline \multicolumn{8}{|l|}{ Balance of payments (SNZ billion) } \\
\hline Current account & -2.8 & -3.9 & -6.9 & -6.0 & -6.8 & & -6.1 \\
\hline (in percent of $\mathrm{GDP}$ ) & $-(3.1)$ & $-(4.1)$ & $-(7.1)$ & $-(6.1)$ & $-(6.7)$ & & $-(5.8)$ \\
\hline Trade balance (goods) & 1.4 & 0.7 & 1.1 & 1.6 & 0.7 & & 1.1 \\
\hline Exports & 20.5 & 20.6 & 21.2 & 22.6 & 23.0 & & 24.8 \\
\hline Imports & -19.2 & -39.9 & -20.0 & -21.0 & -22.3 & & -23.7 \\
\hline Terms of trade (percent change) & -1.6 & -1.0 & -1.6 & 0.9 & -3.1 & & 0.0 \\
\hline \multicolumn{8}{|l|}{ Foreign assets and lisbilities (SNZ billion) $7 /$} \\
\hline Net international investment position 8 & -71.1 & .90 .9 & .79 .9 & -89.5 & -96.1 & & .103 .2 \\
\hline (in percent of GDP) & $-(82,0)$ & $-(77.5)$ & $-(84: 1)$ & $-(91.3)$ & $-(97.1)$ & & $-(99.0)$ \\
\hline Short-term foreign debt $9 /$ & 33.3 & 36.9 & 37.9 & 40.9 & 43.8 & & $\ldots$ \\
\hline of which: Foreign-curnency denominated & 17.0 & 15.0 & 19.2 & 22.4 & 27.9 & & $\ldots$ \\
\hline Official reserves & 6.3 & 6.8 & 6.5 & 7.6 & 7.3 & & $7.05 t$ \\
\hline \multicolumn{8}{|l|}{ Exchange rate (end of period) } \\
\hline USS/SNZ & 0.653 & 0.706 & 0.582 & 0.528 & 0.528 & $6 /$ & $\ldots$ \\
\hline TWT 10 I & 62.3 & 67.5 & 62.2 & 55.4 & 56.8 & 61 & $\ldots$ \\
\hline Nominal effootive exchange rate 11 / & 105.7 & 116.9 & 109.6 & 94.1 & 102.5 & $12 /$ & $\ldots$ \\
\hline Real effective exchange rate $11 /$ & 100.2 & 111.1 & 103.4 & 88.1 & 95.2 & 12 & ... \\
\hline
\end{tabular}

Sources: Data provided by the Now Zealand authorities; and Fund staff estimates and projections.

1/ Estinate of national saving equals invesment plus current account balance excluding migrants' transfers. $2 /$ Fiscal year ending June 30.

3/ Equals revenue less expenditure plus net surplus attributable to state-owned and Croun entities.

4/ Staff estimates; equals operating balance net of revaluations and changes in accounting rules.

5/ June 1999.

6) July 1999.

$7 /$ Data for end-March of each year.

8 Data based on International Investrnent Position statistios.

9/ Residual maturity of less than one year; data based on Total Overseas Debt statistics.

10/ Trade-weighted index (June $1979=100$ ).

11/ IMF Information Notice System index $(1990=100)$.

$12 /$ May 1999. 
Table 2. New Zealand: Balance of Payments and External Debt, 1994-99

(In percent of GDP)

\begin{tabular}{|c|c|c|c|c|c|c|}
\hline & 1994 & 1995 & 1996 & 1997 & 1998 & $\frac{\text { Proj. }}{1999}$ \\
\hline Current account balance & -2.2 & -3.1 & -4.1 & -7.1 & -6.1 & -6.7 \\
\hline Trade balance & 2.7 & 1.5 & 0.8 & 1.2 & 1.6 & 0.7 \\
\hline Exports, f.o.b. & 23.7 & 22.7 & 21.8 & 21.8 & 23.0 & 22.8 \\
\hline Imports, fo.b. & -21.0 & -21.2 & -21.0 & -20.6 & -21.4 & .22 .0 \\
\hline Services balance & -0.6 & -0.3 & -0.5 & -1.1 & -1.6 & -0.3 \\
\hline Receipts & 7.3 & 7.6 & 7.3 & 6.7 & 7.2 & 8.5 \\
\hline Payments & -7.9 & -7.9 & -7.8 & -7.8 & -8.7 & -8.8 \\
\hline Income balance & -6.5 & -6.7 & -7.3 & -8.0 & -6.9 & -7.4 \\
\hline Receipts & 0.7 & 1.6 & 0.6 & 0.3 & 0.0 & 1.0 \\
\hline Payments & -7.2 & -8.2 & -7.8 & -8.3 & -6.8 & -8.4 \\
\hline Transfers balance & 2.2 & 2.4 & 2.9 & 0.9 & 0.8 & 0.3 \\
\hline Inflows & 3.5 & 3.7 & 4.2 & 2.3 & 2.3 & 1.9 \\
\hline Outflows & $-1,3$ & -1.3 & -1.3 & -1.4 & -1.5 & -1.6 \\
\hline Capital and financial account balance 1/ & 2.4 & 2.1 & 7.5 & 5.5 & 5.7 & $\ldots$ \\
\hline Capital account (net) & 1.2 & 2.1 & 2.1 & 0.4 & 0.7 & $\ldots$ \\
\hline Financial account (net) & 4.4 & 7.9 & 5.5 & 5.2 & 5.0 & $\ldots$ \\
\hline Direct investment (net) & 1.6 & 6.7 & 5.8 & 4.2 & 3.4 & $\ldots$ \\
\hline Portfolio investment (net) & 1.1 & -0.3 & -0.8 & -3.5 & -4.7 & $\ldots$ \\
\hline Equity securities (net) & -0.3 & -0.5 & -0.3 & -1.4 & -2.0 & $\ldots$ \\
\hline Debt securities (net) & 1.3 & 0.2 & -0.6 & -2.1 & -2.8 & ... \\
\hline Other investment (net) & 1.7 & 1.4 & 0.5 & 4.5 & 6.3 & $\cdots$ \\
\hline Net errors and omissions 2 & 1.3 & 1.7 & -0.7 & -0.7 & -0.5 & ... \\
\hline \multirow[t]{2}{*}{ Overall balance $3 /$} & 1.4 & 0.6 & 2.7 & -2.2 & -0.9 & ... \\
\hline & \multicolumn{6}{|c|}{ (Assets and Liabilities as of end-March) } \\
\hline Total external debt 4/ & 89.7 & 80.7 & 82.5 & 83.8 & 101.6 & 103.3 \\
\hline Short-term 5/ & 42.7 & 38.4 & 40.4 & 39.9 & 41.8 & 44.4 \\
\hline Long-term & 44.7 & 40.1 & 39.1 & 41.3 & 56.9 & 54.0 \\
\hline Unallocated estimate & 2.3 & 2.2 & 3.0 & 2.6 & 3.0 & 5.0 \\
\hline Net international investment position 6 / & -83.3 & -82.0 & -77.5 & -84.1 & -91.3 & -97.3 \\
\hline Net equity & -15.8 & -19.5 & -17.1 & -19.7 & -23.5 & ... \\
\hline Net debt & -67.5 & -62.4 & -60.4 & -64.3 & -67.8 & $\ldots$ \\
\hline Official reserves & 8.5 & 7.0 & 7.4 & 6.8 & 7.7 & 7.4 \\
\hline (in months of future imports of g\&s) & (3.3) & (2.9) & (3.0) & (2.8) & (3.0) & $(2.8)$ \\
\hline (as percent of short-term debt 5 ) & $(20.0)$ & (18.3) & (18.3) & (17.1) & (18.5) & (16.6) \\
\hline
\end{tabular}

Sources: Data provided by the New Zealand euthorities; and Fund staff estimates and projections.

1/ Based on IFS data; The figure for 1998 represents first quarter at annual rate.

2/ Calculated as a residual.

3/ Based on IFS data.

4/ Data based on Total Overseas Debt statistics.

5/ Residual maturity of less than one year.

6/ Data based on International Investment Position statistics; staff projections for 1999. 
Table 3. New Zealand: Central Government Budget, 1994/95-2001/02 1/

(In percent of GDP)

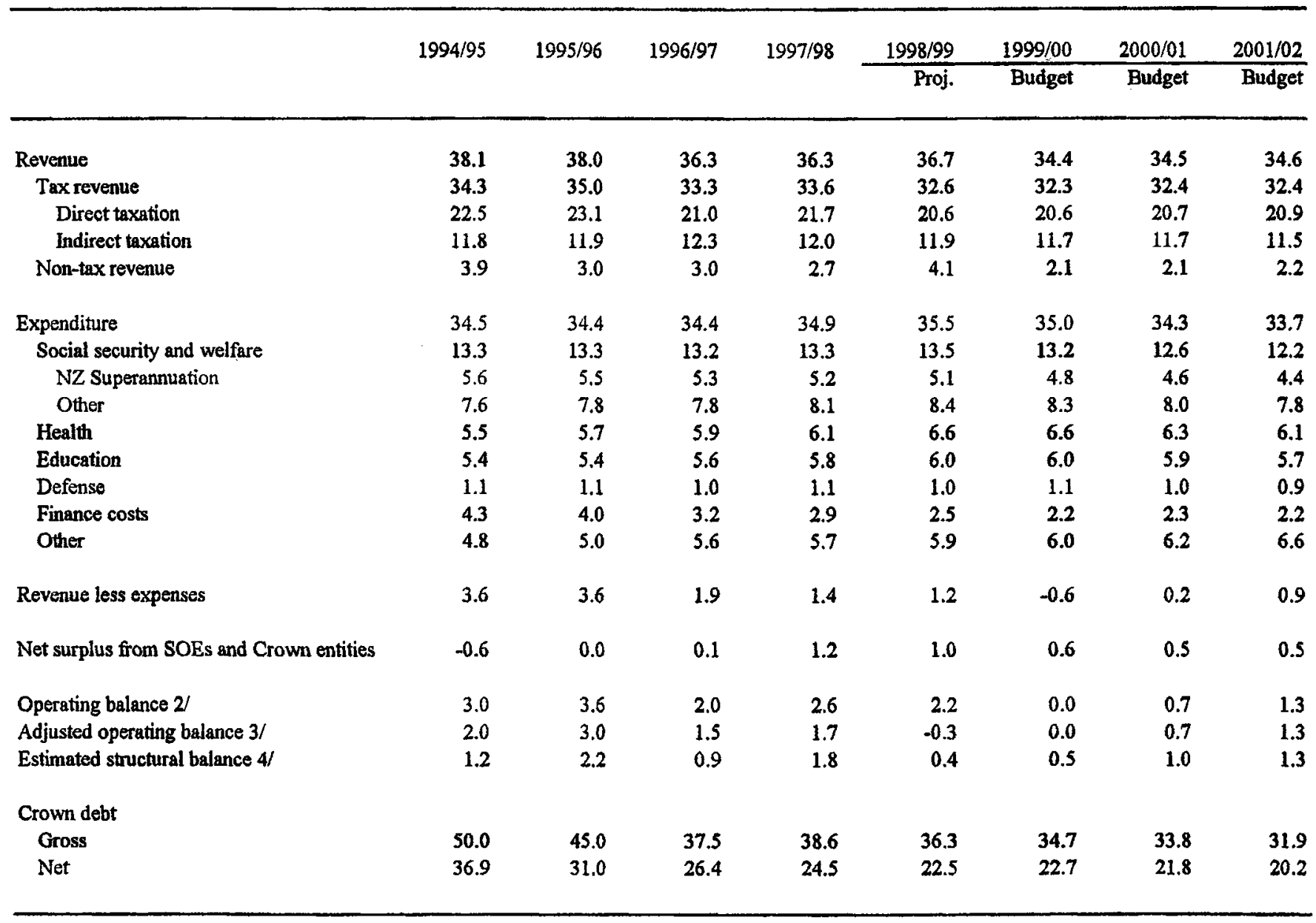

Source: New Zealand Treasury, Budget Economic and Fiscal Update; and staff estimates and projections.

1/ Fiscal year ending June 30;

2/ Equals revenue less expenditure plus net surplus attributable to state-owned and Crown entities.

3/ Staff estimates; equals operating balance net of revaluations and changes in accounting rules.

4/ Staff estimates; equals adjusted operating balance net of cyclical effects. 


\section{NEW ZEALAND-MEDIUM-TERM SCENARIo}

This scenario provides an assessment of the medium-term dynamics of key economic variables such as growth, inflation, and the current account. In particular, it attempts to assess the impact of the authorities' medium-term fiscal consolidation plans and the depreciation of the New Zealand dollar since mid-1997 on the dynamics of the current account deficit and net external liabilities.

Given the strong dependence of the New Zealand economy on the external environment, the economic outlook is largely conditioned by future regional and global developments. The scenario presented here is consistent with the latest global WEO projections of partnercountry demand and world prices for New Zealand's exports and imports.

Following the resumption of growth in mid-1998, output is projected to continue to recover at a modest pace. In 1999 , growth of about $2 \frac{1}{2}$ percent is projected, reflecting a strong pickup in domestic demand, which more than offsets a negative contribution from net exports, the latter mainly on account of a large defense-related import item expected in the second half of the year. The current account deficit is projected to widen to about $63 / 4$ percent of GDP in 1999 (though, adjusted for an one-off import item, the external deficit should remain at about its 1998 level). Inflation is projected to remain subdued, as a result of the significant negative output gap, estimated at 1 1/2-2 percent for the first half of 1999 .

Over the medium term, growth is projected to peak at 3-31/2 percent over the years 2000 and 2001 (closing the negative output gap) and then to gradually slow to its medium-term potential rate of about $2 \frac{1}{2}$ percent. The current account deficit is projected to fall steadily (reaching about $3 \frac{1}{2}$ percent of GDP in 2004), mainly due to a gradual improvement in the trade balance. This is based on a projected firm recovery in import demand in trading partners, and the lagged impact of stronger competitiveness as a result of the large real effective depreciation of the New Zealand dollar (almost 20 percent since mid-1997). Net foreign liabilities are projected to continue to increase in relation to GDP for several more years, peaking at over 100 percent of GDP around 2003. Inflation is projected to remain close to the midpoint of the authorities' 0-3 percent target band over the medium-term.

In terms of the saving-investment balance, the improvement in the current account is projected to occur as a result of higher national saving, which more than offset the cyclical recovery in investment rates from their depressed levels in 1998-99. Higher national saving rates are expected due to increases in both public saving (in line with the authorities' medium-term fiscal projections) and private saving, the latter reflecting both the impact of high household debt levels and the leveling-off of household net worth since 1997, following sizable increases during the 1990 s. 
New Zealand: Medium-Term Scenario, 1995-2004

\begin{tabular}{|c|c|c|c|c|c|c|c|c|c|c|c|}
\hline & \multirow{2}{*}{$\frac{\text { Average }}{1990-94}$} & \multirow[b]{2}{*}{1995} & \multirow[b]{2}{*}{1996} & \multirow[b]{2}{*}{1997} & \multirow[b]{2}{*}{1998} & \multicolumn{6}{|c|}{ Proj. } \\
\hline & & & & & & 1999 & 2000 & 2001 & 2002 & 2003 & 2004 \\
\hline \multicolumn{12}{|l|}{ Real gnowth (percent change) } \\
\hline GDP & 2.0 & 4.0 & 3.1 & 2.1 & -0.3 & 2.6 & 3.3 & 3.3 & 2.8 & 2.7 & 2.6 \\
\hline Domestic demand & 1.4 & 5.1 & 3.9 & 3.2 & 0.2 & 3.9 & 2.8 & 3.1 & 2.5 & 2.4 & 2.2 \\
\hline Consumption & 1.0 & 4.2 & 4.2 & 3.4 & 1.1 & 3.2 & 1.6 & 2.0 & 2.0 & 2.0 & 2.0 \\
\hline Private consumption & 1.1 & 4.6 & 4.6 & 2.8 & 1.6 & 2.7 & 2.5 & 2.2 & 2.0 & 2.0 & 2.0 \\
\hline Fixed Investment & 2.6 & 12.2 & 6.2 & 2.7 & -1.1 & 5.1 & 5.6 & 6.7 & 4.4 & 3.7 & 3.2 \\
\hline Exports of goods and services & 6.7 & 3.8 & 3.5 & 2.9 & 1.5 & 5.6 & 6.1 & 6.8 & 6.6 & 6.5 & 6.6 \\
\hline (Imports in trading partners) & (6.1) & $(11.1)$ & $(8.3)$ & $(8.4)$ & $-(0.1)$ & $(6.3)$ & $(5.8)$ & $(6.7)$ & $(6.5)$ & $(6.5)$ & $(6.5)$ \\
\hline Imports of goods and services & 4.8 & 9.1 & 8.2 & 4.0 & 2.8 & 7.6 & 4.4 & 6.1 & 5.7 & 5.5 & 5.4 \\
\hline \multicolumn{12}{|l|}{ Saving and investment (percent of GDP) } \\
\hline Gross capital formation & 18.9 & 22.4 & 22.0 & 20.9 & 19.3 & 19.0 & 19.7 & 20.3 & 20.5 & 20.6 & 20.6 \\
\hline Fixed investment & 18.0 & 21.0 & 21.2 & 20.2 & 19.1 & 18.6 & 19.1 & 19.6 & 19.9 & 20.0 & 20.0 \\
\hline Increase in stocks & 1.0 & 1.4 & 0.8 & 0.7 & 0.3 & 0.4 & 0.7 & 0.7 & 0.7 & 0.7 & 0.7 \\
\hline National saving $1 /$ & 15.0 & 17.1 & 15.1 & 13.5 & 13.2 & 12.1 & 13.6 & 14.4 & 15.3 & 15.8 & 16.4 \\
\hline Private & 13.7 & 11.2 & 9.0 & 8.5 & 8.3 & 8.9 & 8.8 & 9.8 & 9.8 & 10.2 & 10.3 \\
\hline Public & 2.3 & 5.9 & 6.1 & 5.3 & 4.2 & 3.3 & 3.8 & 4.6 & 5.1 & 5.5 & 5.9 \\
\hline \multicolumn{12}{|c|}{ Inflation, unemployment, and the output gap (pencent) } \\
\hline CPIX inflation & 3.0 & 2.4 & 2.3 & 1.7 & 1.5 & 1.3 & 1.9 & 1.6 & 1.6 & 1.6 & 1.6 \\
\hline Unemployment rate & 9.2 & 6.3 & 6.1 & 6.6 & 7.5 & 7.2 & 7.0 & 6.7 & 6.4 & 6.2 & 6.0 \\
\hline Output gap & -0.9 & 1.1 & 1.0 & 0.6 & -1.9 & -1.6 & -0.8 & -0.1 & 0.0 & 0.0 & 0.0 \\
\hline \multicolumn{12}{|c|}{ Government budget (percent of GDP, years ending June 30) } \\
\hline Revenue & 38.7 & 38.1 & 38.0 & 36.3 & 36.3 & 36.7 & 34.4 & 34.3 & 34.6 & 34.6 & 34.6 \\
\hline Expenditure & 41.1 & 34.5 & 34.4 & 34.4 & 34.9 & 35.5 & 35.0 & 34.3 & 33.7 & 33.3 & 32.9 \\
\hline Operating balance & -2.1 & 3.0 & 3.6 & 2.0 & 2.6 & 2.2 & 0.0 & 0.7 & 1.3 & 1.7 & 2.1 \\
\hline Adjusted operating balance $2 /$ & -2.7 & 2.0 & 3.0 & 1.5 & 1.7 & -0.3 & 0.0 & 0.7 & 1.3 & 1.7 & 2.1 \\
\hline Estimated structural balance 3 / & -2.3 & 1.2 & 2.2 & 0.9 & 1.8 & 0.4 & 0.5 & 1.0 & 1.3 & 1.7 & 2.1 \\
\hline Net Crown debt & 46.0 & 36.9 & 31.0 & 26.4 & 24.5 & 22.5 & 22.7 & 21.8 & 20.2 & 18.6 & 16.6 \\
\hline Terms of trade (percent change, goods) & -0.7 & -1.6 & -1.0 & -1.6 & 0.9 & -3.1 & 0.0 & 0.2 & -0.1 & 0.0 & 0.0 \\
\hline \multicolumn{12}{|l|}{ Balance of payments (percent of GDP) } \\
\hline Current account balance & -2.2 & -3.1 & -4.1 & -7.1 & -6.1 & -6.7 & -5.8 & -5.3 & -4.6 & -4.1 & -3.5 \\
\hline Batance on goods and services & 1.9 & 1.2 & 0.3 & 0.1 & 0.0 & 0.4 & 1.0 & 1.4 & 1.8 & 2.3 & 2.9 \\
\hline Balance on income and transfers & -4.1 & -4.3 & -4.4 & -7.1 & -6.1 & -7.1 & -6.8 & -6.7 & -6.3 & -6.4 & -6.4 \\
\hline CA balance on BPMS basis (estimated) & -3.2 & -7.1 & -7.2 & -7.4 & -6.2 & -6.9 & -6.2 & -5.9 & -5.3 & -4.8 & -4.2 \\
\hline Net foreign liabilities (percent of GDP) & & 78.3 & 82.1 & 89.5 & 96.7 & 100.7 & 101.9 & 103.0 & 103.9 & 104.2 & 104.0 \\
\hline
\end{tabular}

Sources: Data provided by the New Zealand authorities; and staff estimates and projections.

1/ Staff estimates; based on national accounts data.

2/ Staff estimates; equals operating balance net of revaluations and changes in accounting rules.

3/ Staff estimates; equals adjusted operating balance net of cyclical effects. 


\section{NEW ZEALAND-FUND RELATIONS}

(As of June 30, 1999)

I. Membership Status: Joined: 08/31/1961; Article VIII

II. General Resources Account:

Quota

Fund Holdings of Currency

Reserve position in Fund

Operational budget transfers(net)

III. SDR Department:

Net cumulative allocation

Holdings

Designation Plan
SDR Million

894.60

553.41

341.21

5.00
Percent Quota

100.0

61.9

38.1

\section{SDR Million}

141.32

Percent Allocation

100.0

2.66

1.9

15.00

IV. Outstanding Purchases and Loans: None

V. Financial Arrangements: None

VI. Projected Obligations to Fund: None

\section{Exchange Arrangement:}

The New Zealand dollar has floated freely since March 1985. New Zealand maintains an exchange system that is free of restrictions on international payments and transfers for current and capital transactions, with the exception of restrictions maintained in accordance with relevant U.N. Security Council Resolutions against Iraq, the Federal Republic of Yugoslavia (Serbia/Montenegro), and Libya, and which were all notified to the Fund pursuant to Decision No. 144. In addition, New Zealand has recently enforced restrictions, in accordance with U.N. resolutions, on a military faction in Angola, and is in the process of officially informing the Fund in accordance with Decision No. 144.

\section{Article IV Consultation:}

At the conclusion of the last Article IV consultation, New Zealand was placed on the 24-month cycle. The 1997 consultation discussions were held during July 28-August 7, 1997; the Executive Board discussed the staff report (SM/97/257, 10/17/97) and concluded the consultation on November 7, 1997. An interim staff visit was held in Auckland and Wellington during January 25-28, 1999.

IX. Technical Assistance: None

X. Resident Representative/Advisor: None 


\section{STATISTICAL ISSUES AND Y2K READINESS}

\section{Core statistical indicators}

New Zealand publishes a wide array of economic and financial statistics, and regularly provides the core statistical indicators to the Fund for surveillance.

\section{National accounts}

National accounts data are comprehensive and available on a timely basis, but discrepancies between the production and expenditure measures of GDP, and the absence of quarterly estimates of production- and income-based GDP at current prices, continue to hamper economic analysis.

\section{Consumer price index}

Statistics New Zealand (SNZ) concluded its six-yearly review of the CPI in November 1997. While the review confirmed the essential soundness of the current CPI, it recommended that, going forward, three separate measures of the CPI be compiled, reflecting the different ways of incorporating the cost of housing. SNZ plans to begin publication of the three measures shortly.

\section{Balance of payments}

The monitoring of external financing of the current account deficit is complicated by long reporting lags for annual data on the financial and capital accounts, and international asset and liability data. The authorities plan to publish quarterly data on all of these items, with a lag of no more than 3 months, starting with the June 2000 quarter.

\section{Y2K Readiness}

A "Y2K Readiness Commission" was established, whose role is to advise, monitor, promote and increase the understanding of Y2K risk. The Commission publishes periodic reports, assessing the readiness of various sectors in the economy. Key sectors-including telecommunications, energy, transportation, and finance, as well as the public sector-have been assessed as having a high degree of $\mathrm{Y} 2 \mathrm{~K}$ preparedness. Attention is now focusing on the readiness of small- and medium-sized enterprises, a significant fraction of which started assessing their Y2K risks only recently. 
New Zealand: Core Statistical Indicators

(As of July 15, 1999)

\begin{tabular}{|c|c|c|c|c|c|c|c|c|c|c|c|c|}
\hline & $\begin{array}{c}\text { Exchange } \\
\text { rates }\end{array}$ & $\begin{array}{l}\text { International } \\
\text { reserves }\end{array}$ & $\begin{array}{c}\text { Reserve/ } \\
\text { base } \\
\text { money }\end{array}$ & $\begin{array}{c}\text { Central } \\
\text { Bank } \\
\text { balance } \\
\text { sheet }\end{array}$ & $\begin{array}{l}\text { Broad } \\
\text { money }\end{array}$ & $\begin{array}{l}\text { Interest } \\
\text { rates }\end{array}$ & $\begin{array}{l}\text { Consumer } \\
\text { price } \\
\text { index }\end{array}$ & $\begin{array}{c}\text { Exports/ } \\
\text { imports }\end{array}$ & $\begin{array}{l}\text { Current } \\
\text { account } \\
\text { balance }\end{array}$ & $\begin{array}{l}\text { Overall } \\
\text { government } \\
\text { balance }\end{array}$ & $\begin{array}{l}\text { External } \\
\text { public debt }\end{array}$ & GDP/GNP \\
\hline $\begin{array}{l}\text { Date of latest } \\
\text { observation }\end{array}$ & $7 / 15 / 99$ & May 1999 & May 1999 & May 1999 & May 1999 & $7 / 15 / 99$ & June 1999 & May 1999 & Mar. 1999 & May 1999 & Mar. 1999 & Mar. 1999 \\
\hline Date received & $7 / 15 / 99$ & $6 / 18 / 99$ & $6 / 30 / 99$ & $6 / 30 / 99$ & $6 / 30 / 99$ & $7 / 15 / 99$ & $7 / 15 / 99$ & $6 / 9 / 99$ & $6 / 18 / 99$ & $7 / 2 / 99$ & $6 / 15 / 99$ & $6 / 25 / 99$ \\
\hline $\begin{array}{l}\text { Frequency of } \\
\text { data }\end{array}$ & Daily & Monthly & Weekly & Monthly & Monthly & Daily & Quarterly & Monthly & Quarterly & Monthly & Quarterly & Quarterly \\
\hline $\begin{array}{l}\text { Frequency of } \\
\text { reporting }\end{array}$ & Daily & Monthly & Weekly & Monthly & Monthly & Daily & Quarterly & Monthly & Quarterly & Monthly & Quarterly & Quarterly \\
\hline Source of data & Reuters & RBNZ/IFS & RBNZ & RBNZ & RBNZ & Reuters & Reuters & Reuters & SNZ & Treasury & RBNZ & SNZ \\
\hline $\begin{array}{l}\text { Mode of } \\
\text { reporting }\end{array}$ & Electronic & Electronic & Electronic & Electronic & Electronic & Electronic & Electronic & Electronic & Electronic & Reuters & Electronic & Electronic \\
\hline Confidentiality & Public & Public & Public & Public & Public & Public & Public & Public & Public & Public & Public & Public \\
\hline $\begin{array}{l}\text { Frequency of } \\
\text { publication }\end{array}$ & Daily & Monthly & Weekly & Monthly & Monthly & Daily & Quarterly & Monthly & Quarterly & Monthly & Quarterly & Quarterly \\
\hline
\end{tabular}


This page intentionally left blank 


\section{Statement by the IMF Staff Representative August 30, 1999}

1. This buff contains information that has become available since the staff report (SM/99/196, 8/3/99) was circulated to the Executive Board on August 3. This information does not affect the staff appraisal.

\section{Economic Outlook for 1999 and Recent Financial Market Developments}

2. Recent indicators suggest that the economic recovery that began in the third quarter of 1998 is continuing, and should unfold broadly as envisaged in the staff report. Consents issued for new dwellings have shown healthy growth in recent months, suggesting that the recovery in building investment is continuing. Credit to households has also picked up in tandem with the recovery in the housing market, but retail sales have remained relatively flat. Although agricultural exports remain weak as a result of the lagged impact of two consecutive droughts, exports of services (especially tourism) have increased strongly. The latest consensus forecast, released on August 9, projects growth of 2.5 percent in 1999, about the same as projected in the staff report ( 2.6 percent).

3. From its level at end-July, the New Zealand dollar has depreciated by about 2 percent, both against the U.S. dollar and on a trade-weighted basis. As a result of the lower value of the Trade-Weighted Index (TWI), the Monetary Conditions Index (MCI) - a weighted average of the TWI and 90-day interest rates-fell during August reaching about $\mathbf{- 3 5 0}$ on August 27, about 100-basis points lower than at the end of July. Long-term interest rates picked up from about $61 / 2$ percent in early July to nearly 7 percent in recent days. While this partly reflects higher bond yields in international markets, the yield differential between New Zealand and comparable U.S. bonds has also widened from 70-basis points in early July to about 100-basis points in recent days. This widening of the risk premium may reflect both concerns about the growing external imbalance, as well as political uncertainties in the runup to elections that must take place before year-end.

\section{Monetary Policy Statement}

4. On August 18, the Reserve Bank of New Zealand released its quarterly Monetary Policy Statement (MPS). In it, the Bank decided to leave the Official Cash Rate (OCR) unchanged at 4.5 percent. However, with the recovery more assured now than in May when the previous MPS was released and with the external environment facing New Zealand more robust, the Bank stated that the firming in monetary conditions needed to prevent the emergence of inflationary pressures would likely require an increase in the OCR before the end of 1999, somewhat earlier than had been foreseen in the May statement. 


\section{Tax Cuts}

5. The government recently proposed a package of personal income tax cuts totaling NZ $\$ 400$ million (0.4 percent of GDP) with effect from April 1, 2000. The main element of the package is a reduction in the middle personal tax rate from 21 percent to 20 percent and an increase in the threshold for the top income tax rate (33 percent) from NZ\$38,000 to NZ\$40,000. The government has not indicated how these tax cuts would be funded, but a paper on the funding implications is expected to be submitted to Cabinet in time for inclusion in the pre-election Economic and Fiscal Update. The legislation for the proposed tax cuts has not been presented to Parliament.

\section{Staff assessment}

6. The staff broadly endorses the Reserve Bank's judgment on the need to bring forward somewhat the timing of a likely future increase in the OCR. The external environment facing New Zealand has indeed improved in recent months, reflecting upward revisions to growth prospects for 1999 in many Asian countries, Australia, and Japan. This is likely to give a fillip to the New Zealand economy and the staff sees some slight upward risk to its projection for GDP growth in 2000. The improved outlook should result in a somewhat more rapid closing of the output gap than was foreseen by the Reserve Bank in May.

7. At the same time, staff would urge the authorities to continue to monitor developments closely, and to keep an open mind on the appropriate timing of a future OCR increase. There continue to be risks that the recovery in Asia and Japan will encounter hiccups. In addition, while the Reserve Bank's survey of expectations indicates some prospect of a pickup in wage growth in 2000 , at present labor costs are showing only modest growth, and the latest consensus forecast does not foresee any significant pickup in labor costs either this year or next. Further, the rise in long-term bond yields, and the still fragile state of business confidence according to recent surveys, are likely to exert downward pressure on future demand growth, and hence slow somewhat the pace at which the negative output gap narrows. Therefore, to sum up, while the impact on New Zealand of the more robust external environment suggests the need to tighten policy earlier than previously envisaged, a number of other factors suggest the need to keep the issue of the timing of such a move under close review.

8. With regard to tax cuts, the staff supports the principle of reducing the direct tax burden in New Zealand (paragraphs 22 and 43 of the staff report). However, there is a need to safeguard the credibility of the authorities' stated long-term fiscal goals and to prevent any potential weakening of market sentiment that could be engendered by a slowing of progress toward achieving those goals. In this regard, the staff has taken the position that tax cuts should not lead to any slippages in the envisaged paths of operating surplus increases or net debt reduction. While no decisions have been announced on how tax cuts will be funded, the staff would continue to underscore the importance of achieving at least as ambitious a path of fiscal consolidation as envisaged in the latest Fiscal Strategy Report. 


\section{IMF Concludes Article IV Consultation with New Zealand}

On August 30,1999, the Executive Board concluded the Article IV consultation with New Zealand. ${ }^{1}$

\section{Background}

Since the mid-1980s, New Zealand has been engaged in a comprehensive reform effort designed to improve its economic performance. Reflecting the success of this effort, economic performance improved during the 1990s. Inflation averaged about 2 percent, compared to nearly 10 percent in the 1980s, while economic growth also picked up. And, thanks to strong budget surpluses, net public debt has been reduced by half, and has now reached relatively low levels by international standards. Despite these improvements, the current account deficit remains very high, increasing the economy's vulnerability to external shocks. And, while growth performance has improved, most estimates suggest that the potential growth rate remains too low to close the per capita income gap between New Zealand and the advanced-economy average.

Since mid-1997, New Zealand was hit by a string of unfavorable shocks which, combined with high real interest rates and a strong New Zealand dollar in 1996-97, served to push the economy into recession at the beginning of 1998. In addition to the collapse in demand from crisis-hit Asia, the economy was affected by severe drought, and by continued weakness in the terms of trade. Overlaid on these shocks was the impact of very firm monetary conditions that had been established in a period when forecasts portended continued strong demand growth.

\footnotetext{
'Under Article IV of the IMF's Articles of Agreement, the IMF holds bilateral discussions with members, usually every year. A staff team visits the country, collects economic and financial information, and discusses with officials the country's economic developments and policies. On return to headquarters, the staff prepares a report, which forms the basis for discussion by the Executive Board. At the conclusion of the discussion, the Managing Director, as Chairman of the Board, summarizes the views of Executive Directors, and this summary is transmitted to the country's authorities. In this PIN, the main features of the Board's discussion are described.
} 
Recession proved short-lived, however, and a recovery was underway by the second half of 1998 , aided by both a significant easing in monetary conditions and tariff and income tax cuts.

The current account deficit narrowed in 1998, reflecting the weakness of the domestic economy and competitiveness gains, but remained well above the level that would stabilize the net external liabilities/GDP ratio. While the domestic recession dampened imports and dividend payments to nonresidents, other factors prevented a stronger improvement. These included weak cyclical conditions in trading partners; adverse terms of trade; supply constraints on agricultural exports; and poor returns on foreign investments. As a result, the net external liabilities ratio-already the highest among industrial countries-rose further.

Importantly, sizable current account deficits since the mid-1990s have coexisted with fiscal surpluses, consistent with a key tenet of the Fiscal Responsibility Act, which requires that public debt be reduced to "prudent" levels. In this vein, the authorities have run operating surpluses of 2-3 percent of GDP over the past five years, while net public debt has been reduced by some 15 percent of GDP over the same period, and stands at 22 percent of GDP, 7 percent above the authorities' stated long-term target for a "prudent" level of net Crown debt. Less progress has been made in respect of another long-term objective-to reduce government spending below 30 percent of GDP-mainly because of pressures to increase social expenditure.

The budgetary outturn for 1998/99 includes several one-off factors that boosted the operating surplus in that year, but that have no impact on the structural fiscal position. Adjusting for these, and for cyclical factors, the structural balance-while still in surplus-is much lower than its average level since the mid-1990s. The main factor explaining the fall in the structural surplus in 1998/99 is income tax cuts introduced in mid-1998, the second such tax cut since mid-1996.

Monetary policy has continued to be directed at achieving annual inflation (excluding credit services, CPIX) of between 0 and 3 percent. Monetary conditions began to ease in early 1997, and the easing gathered momentum in 1998. With recovery underway by the second half of 1998, a modest firming has taken place since late-1998, although the Monetary Conditions Index $(\mathrm{MCl})$ remains significantly easier than at the beginning of last year. From March 1999, the Reserve Bank began to use the Official Cash Rate (OCR) as its primary policy instrument.

The near-term outlook is for recovery to continue, inflation to remain subdued, and the current account deficit to widen slightly in 1999 before coming down in 2000. Weak terms of trade and supply constraints on agricultural exports will limit the near-term adjustment in the current account, while the import of a navy frigate will boost imports by $1 / 2$ percent of GDP in 1999. A more hospitable external environment, and the disappearance of one-off factors on the import side, should, however, see the external deficit significantly reduced in 2000. Inflation should remain near the midpoint of the target range throughout the forecast horizon, although this will imply some continued firming in monetary conditions as the output gap is reduced. Over the medium term, fiscal consolidation and some recovery in household saving should support the adjustment in the current account and a slow decline in the net external liabilities ratio. 


\section{Executive Board Assessment}

Executive Directors commended the authorities for their skillful economic management, noting that-despite the impact of recession in key Asian export markets and severe drought-economic outcomes in New Zealand had nonetheless been relatively favorable. While the economy experienced recession in the first half of last year, a recovery was underway by the second half, and has gathered momentum. Directors considered that other aspects of New Zealand's strong economic performance, including low inflation, low public debt, and the absence of distress in either the corporate or financial sectors, were further testimony to the economy's resilience under adverse circumstances. In the view of Directors, this resilience was itself a key payoff from 15 years of economic reform that had completely transformed the New Zealand economy.

Directors noted, however, that New Zealand continues to face some difficult economic challenges that warranted the continued attention of policy makers: first, the vulnerabilities associated with the large external deficit and debt; and second, the need to sustain the recent improvement in productivity growth.

Directors considered that near-term macroeconomic policies were broadly appropriate in light of the external risks. The relatively easy level of monetary conditions-especially the fall in the New Zealand dollar since mid-1997-combined with the authorities' intention to adhere to a path of rising budgetary surpluses through 2001/02, should help to support external adjustment without compromising the economic recovery.

At the same time, with the output gap expected to narrow somewhat more rapidly than was foreseen several months ago, Directors endorsed the Reserve Bank's readiness to tighten monetary conditions earlier than was envisaged at that time, if necessary.

Directors noted that monetary policy could be faced with a number of shocks in the period ahead, including a possible shift in market sentiment that would exert downward pressure on the currency and push up the risk premium. In these circumstances, Directors considered that the authorities should continue to be guided by their monetary policy framework, which allowed for some near-term volatility in inflation, while remaining firmly focused on medium-term price stability.

Directors considered that near-term fiscal policy should also continue to be set with both the external risks and long-term fiscal objectives in mind. In this regard, they emphasized the importance of avoiding a budget deficit this fiscal year, and of gradually building up surpluses over the subsequent two years, both in order to enhance the credibility of the authorities' commitment to their stated long-term fiscal objectives for expenditure and debt, and in order to bolster market confidence during a period in which the current account deficit is expected to remain at very high levels. Directors underscored the desirability of achieving a path of fiscal consolidation that will be at least as ambitious as that envisaged in the latest Fiscal Strategy Report. 
Directors observed that the key long-term budgetary issues were those associated with population aging, and commended the authorities' early consideration of such issues. In this regard, Directors saw merit in building up the operating surplus over the medium term through continued expenditure control, as recommended by the staff. Not only was such a strategy essential for achieving the authorities' long-term objective for government expenditure before significant demographic pressures emerged, it was also a prudent course to follow pending decisions being taken on whether and how to reform the pension system.

Directors noted that, although New Zealand was relatively well positioned to cope with exchange rate or interest rate shocks that might occur as a result of an adverse shift in market sentiment, its vulnerability to such shocks called for caution and a continued implementation of strong macroeconomic policies. In addition, Directors suggested that active consideration be given to other measures that could underpin market confidence and external adjustment over the medium term. In this context, they endorsed efforts in train to reduce welfare dependency and the generosity of the state pension scheme. These efforts, in their view, were likely to improve the environment for private saving in New Zealand by encouraging self-provision for retirement and reducing a possibly excessive degree of social insurance provided by the welfare system. In addition, some Directors advised further consideration of tax reforms to remove potential disincentives to private saving, including those associated with the still relatively high proportion of revenue levied through direct taxes.

Directors strongly supported the authorities' structural reforms aimed at boosting the economy's sustainable growth potential, including recent education reforms aimed at helping to improve the skill level of the work force, tariff reductions, and producer board reform.

Directors noted that New Zealand publishes an array of high-quality economic and financial statistics that are adequate for surveillance.

Public Information Notices (PINs) are issued, (i) at the request of a member country, following the conclusion of the Article IV consultation for countries seeking to make known the views of the IMF to the public. This action is intended to strengthen IMF surveillance over the economic policies of member countries by increasing the transparency of the IMF's assessment of these policies; and (ii) following policy discussions in the Executive Board at the decision of the Board. As part of a pilot project, the staff report for the 1999 Article IV consultation with New Zealand is also available. 
New Zealand: Selected Economic and Financial Indicators

\begin{tabular}{|c|c|c|c|c|c|}
\hline & 1995 & 1996 & 1997 & 1998 & $\begin{array}{l}\text { Proj. } \\
1999\end{array}$ \\
\hline & \multicolumn{5}{|c|}{ (Percentage change) } \\
\hline \multicolumn{6}{|l|}{ Real economy } \\
\hline Real GDP & 4.0 & 3.1 & 2.1 & -0.3 & 2.6 \\
\hline Real domestic demand & 5.1 & 3.9 & 3.2 & 0.2 & 3.9 \\
\hline Real exports & 3.8 & 3.5 & 2.9 & 1.5 & 5.6 \\
\hline Real imports & 9.1 & 8.2 & 4.0 & 2.8 & 7.6 \\
\hline Inflation (CPI excluding credit services) & 2.4 & 2.3 & 1.7 & 1.5 & 1.3 \\
\hline Unemployment rate (in percent) & 6.3 & 6.1 & 6.6 & 7.5 & 7.2 \\
\hline Gross national saving (annual percent of GDP) $1 /$ & 17.1 & 15.1 & 13.5 & 13.2 & 12.1 \\
\hline \multirow[t]{2}{*}{ Gross capital formation (annual percent of GDP) } & 22.4 & 22.0 & 20.9 & 19.3 & 19.0 \\
\hline & \multicolumn{5}{|c|}{ (Percent of GDP, years ending June 30 ) } \\
\hline \multicolumn{6}{|l|}{ Government budget } \\
\hline Revenue & 38.1 & 38.0 & 36.3 & 36.3 & 36.7 \\
\hline Expenditure & 34.5 & 34.4 & 34.4 & 34.9 & 35.5 \\
\hline Operating balance & 3.0 & 3.6 & 2.0 & 2.6 & 2.2 \\
\hline \multirow[t]{2}{*}{ Net public debt } & 36.9 & 31.0 & 26.4 & 24.5 & 22.5 \\
\hline & \multicolumn{5}{|c|}{ (End of period) } \\
\hline \multicolumn{6}{|l|}{ Money and credit } \\
\hline M3 (change in percent) & 14.5 & 12.6 & 3.9 & 1.5 & 0.621 \\
\hline Private domestic credit (change in percent) & 15.1 & 12.4 & 10.0 & 7.5 & 9.521 \\
\hline Interest rate (90-day, in percent) & 8.6 & 8.1 & 8.3 & 4.4 & $4.93 /$ \\
\hline \multirow[t]{2}{*}{ Government bond yield (10-year, in percent) } & 7.2 & 7.2 & 7.0 & 5.4 & $7.03 /$ \\
\hline & \multicolumn{5}{|c|}{ (Percent of GDP) } \\
\hline \multicolumn{6}{|l|}{ Balance of payments } \\
\hline Current account balance & -3.1 & -4.1 & -7.1 & -6.1 & -6.7 \\
\hline \multirow[t]{2}{*}{ Capital and financial account } & 2.1 & 7.5 & 5.5 & 5.7 & $\ldots$ \\
\hline & \multicolumn{5}{|c|}{ (Percent of GDP, years ending March 31) } \\
\hline \multicolumn{6}{|l|}{ External assets and liabilities } \\
\hline Official reserves & 7.0 & 7.4 & 6.8 & 7.7 & 7.4 \\
\hline Gross external debt & 80.7 & 82.5 & 83.8 & 101.6 & 103.3 \\
\hline \multirow[t]{2}{*}{ Net external liabilities } & 82.0 & 77.5 & 84.1 & 91.3 & 97.3 \\
\hline & \multicolumn{5}{|c|}{ (End of period) } \\
\hline \multicolumn{6}{|l|}{ Exchange rate } \\
\hline US\$/NZ\$ & 0.653 & 0.706 & 0.582 & 0.528 & $0.5123 /$ \\
\hline Nominal effective exchange rate $4 /$ & 105.7 & 116.9 & 109.6 & 94.1 & 99.621 \\
\hline Real effective exchange rate $4 /$ & 100.2 & 111.1 & 103.4 & 88.0 & 93.021 \\
\hline
\end{tabular}

Sources: Data provided by the New Zealand authorities; and IMF staff estimates and projections.

1/ Staff estimates; based on national accounts

2/ For 1999, June data.

3/ For 1999, August 30 data.

4/ IMF Information Notice System index $(1990=100)$. 